University of San Diego

Digital USD

Theses

Theses and Dissertations

Summer 8-30-2016

\title{
Settlement of larval spotted sand bass (Paralabrax maculatofasciatus) within Mission Bay, San Diego CA in relation to environmental conditions
}

Anthony J. Basilio

University of San Diego

Follow this and additional works at: https://digital.sandiego.edu/theses

Part of the Marine Biology Commons

\section{Digital USD Citation}

Basilio, Anthony J., "Settlement of larval spotted sand bass (Paralabrax maculatofasciatus) within Mission Bay, San Diego CA in relation to environmental conditions" (2016). Theses. 12.

https://digital.sandiego.edu/theses/12

This Thesis: Open Access is brought to you for free and open access by the Theses and Dissertations at Digital USD. It has been accepted for inclusion in Theses by an authorized administrator of Digital USD. For more information, please contact digital@sandiego.edu. 



\section{UNIVERSITY OF SAN DIEGO}

San Diego

Settlement of larval spotted sand bass (Paralabrax maculatofasciatus) within Mission Bay, San Diego CA in relation to environmental conditions

A thesis submitted in partial satisfaction of the requirements for the degree of

Master of Science in Marine Science

by

Anthony J. Basilio

Thesis Committee

Steven Searcy, Ph.D., Chair

Nathalie Reyns, Ph.D.

Andrew Thompson, Ph.D. 
The thesis of Anthony J. Basilio is approved by:

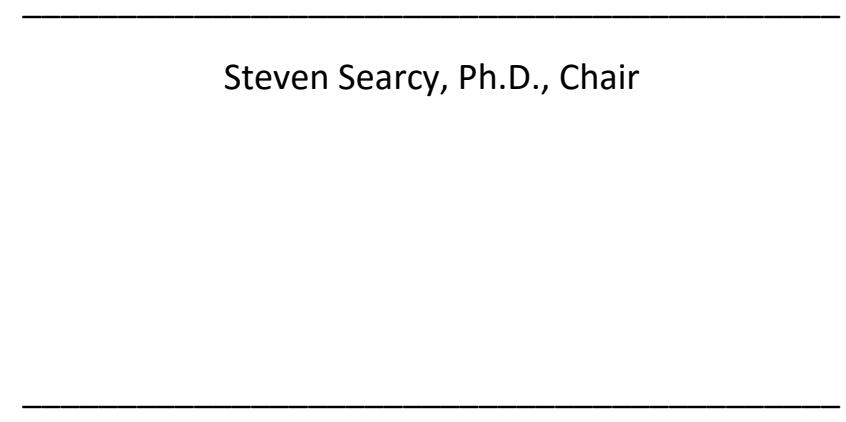

Nathalie Reyns, Ph.D.

Andrew Thompson, Ph.D.

University of San Diego

San Diego

2016 
Copyright 2016 Anthony Basilio 


\section{DEDICATION}

To family and friends, the cornerstone of any successful endeavor. To my advisors, for

helping me every step of the way. To all the fish who gave their lives in the name of science, I could not have done it without you. 


\section{ACKNOWLEDGMENTS}

I would have been lost from day one without the constant support of Steven Searcy, who always helped me stay focused on my goal and develop this study. Nathalie Reyns was always there whenever I needed help clarifying concepts or developing new questions. I would also like to thank Nathalie for providing funding for my research materials. The faculty of the USD EOSC Department provided me with an excellent baseline and introduction to San Diego. Ron Kaufmann's "how to be a graduate student" class was particularly helpful, and in hindsight I truly value everything I learned in that time. The USD grad students were always there to compare laboratory disasters over a beer. Many of my larvae were collected thanks to the combined efforts of USD undergrads Tom Remington, Connell Ford, Matt Ray, Caroline Leinung, Colin Phillips, Craig Foxhoven, and Diana Fontaine. Thanks for all the help!

At Southwest Fisheries Science Center, Andrew Thompson was my stats guru. I learned more about statistics from him in a few short months than the rest of my life combined. The staff of the SWFSC Ichthyoplankton Lab were also incredibly helpful when I needed to barge in and use their lab space for image analysis. Dr. Cindy Bessey created the satellite code that translated Dr. Dave Foley's Xtracto_3D_bdap Matlab code to R, and without their hard work I would not have been able to analyze how chlorophyll and sea surface temperature changed.

Finally, I would like to thank my family and friends for always being supportive and understanding. I could always count on Em Cullen, Emily Gardner, and Elizabeth Smith to cheer me up. I definitely would not have made it through the last year of my project if not for the exploding ball of sunshine that is Laura Reid. I love you all. 


\section{TABLE OF CONTENTS}

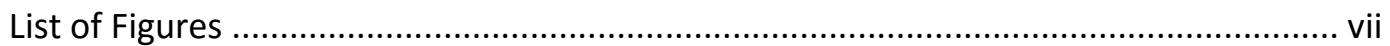

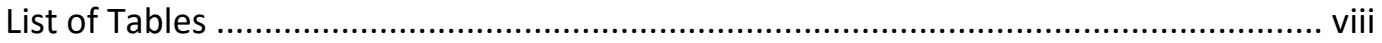

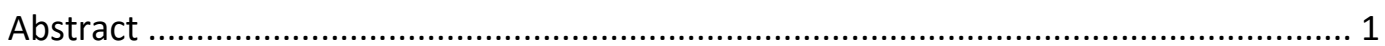

Chapter 1: Introduction to thesis

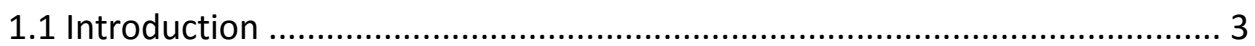

1.1.1 West coast bays and estuaries as critical habitat ......................... 3

1.1.2 Spotted sand bass ................................................................... 3

1.1.3 Chlorophyll and food availability ............................................... 6

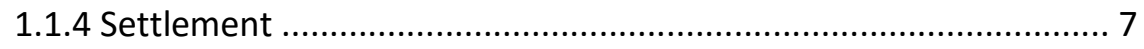

1.1.5 Physical factors influencing settlement ...................................... 9

1.1.6 Southern California Bight oceanography ................................. 12

1.1.7 Measuring settlement ............................................................. 13

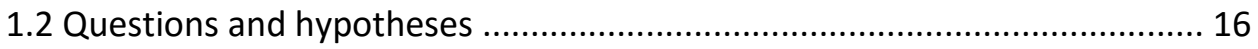

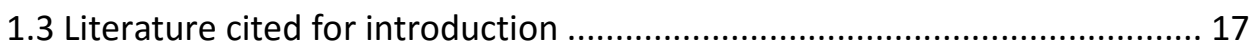

Chapter 2: Settlement of larval spotted sand bass (Paralabrax maculatofasciatus) within Mission Bay, San Diego CA in relation to environmental conditions

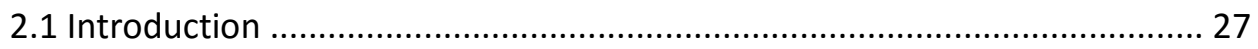

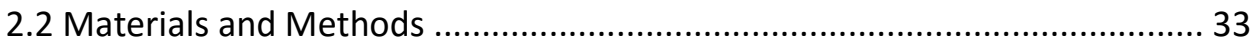

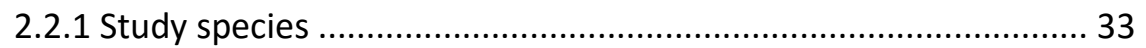

2.2.2 Larval fish collection and morphometric analysis ...................... 34

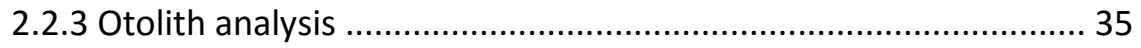

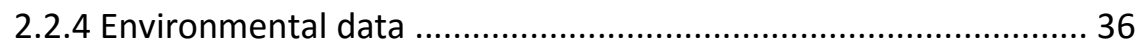

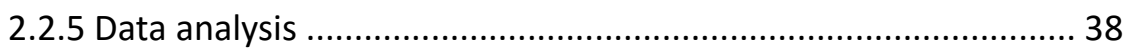

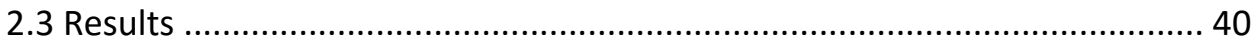

2.3.1 Abundance and Individual Characteristics .................................. 40

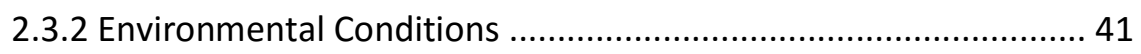

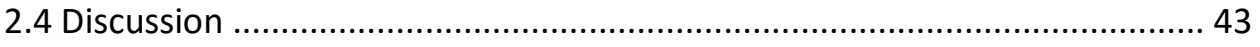

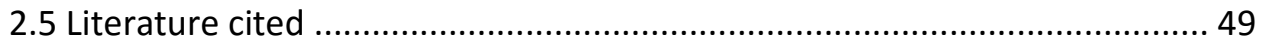




\section{LIST OF FIGURES}

Figure 1. Map of Mission Bay, CA and surrounding water with sampling locations ....... 59

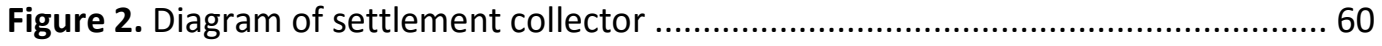

Figure 3. Digital images of otolith with settlement check ......................................... 61

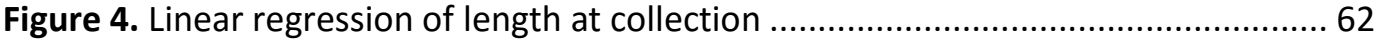

Figure 5. Potential area of spotted sand bass larvae ................................................... 63

Figure 6. Relationship between settlement and lunar period .................................... 64

Figure 7. Annual mean abundance of spotted sand bass collected ..............................65 65

Figure 8. Annual mean standard length at settlement and at collection ......................66 66

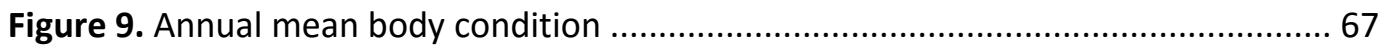

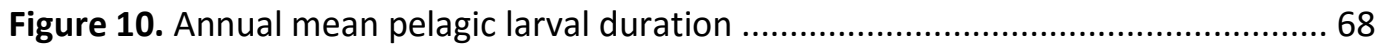

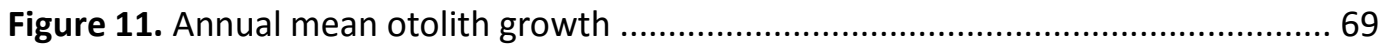

Figure 12. Annual mean sea surface temperature ….................................................... 70

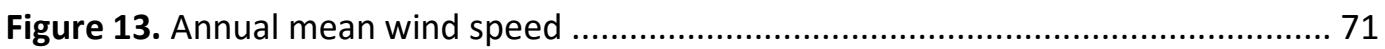

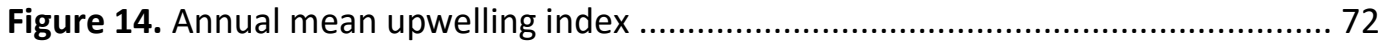

Figure 15. Annual mean alongshore Ekman transport .............................................. 73

Figure 16. Annual mean chlorophyll a concentration ................................................. 74

Figure 17. Relationship between daily chlorophyll a and settlement ........................... 75

Figure 18. Relationship between daily sea surface temperature and settlement .......... 76 


\section{LIST OF TABLES}

Table 1. Summary table for environmental conditions ................................................. 77

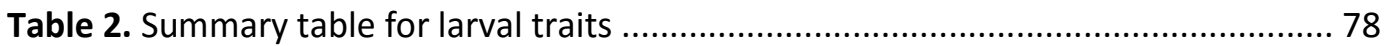

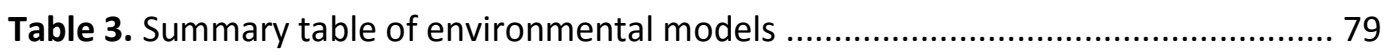

Table 4. Summary table of $95 \%$ confidence intervals for model selection ..................... 81

Table 5. Summary table of repeated measures MANOVA output .................................. 82

Table 6. Summary table of proportion settlement by lunar day ................................... 83

Table 7. Summary table of environmental conditions multiple regression analyses ..... 84 


\begin{abstract}
Many marine fishes spawn in nearshore environments, and produce pelagic larvae that are carried offshore by currents. During pelagic development, larvae experience high rates of mortality due to starvation and predation. Individuals that survive larval development ultimately return to the nearshore environment and settle to juvenile nursery areas where they transition to a benthic-associated lifestyle. Monitoring the number of larvae that have recently settled and how this varies in relation to environmental conditions provides insight into future population strength, which is a fundamental goal of marine ecology as well as fisheries management. This research focused on characterizing the settlement patterns of spotted sand bass (Paralabrax maculatofasciatus), a recreationally important species that utilizes bays and estuaries as nursery habitat.
\end{abstract}

To quantify P. maculatofasciatus settlement patterns, three larval collectors were installed near the mouth of Mission Bay, San Diego CA, and retrieved weekly from June - October of 2012 - 2015. Larvae were counted, and individuals were measured for standard length, dry weight, body condition, as well as otolith derived growth rates and age at settlement. To determine whether environmental conditions affected settlement, or individual characteristics of larvae at settlement, we examined how these factors varied in relation to chlorophyll a (Chl-a), sea surface temperature (SST), wind speed, wave height and direction, alongshore transport and upwelling.

Settlement of $P$. maculatofasciatus was significantly lower in 2014-15, and appeared to be the result of low food conditions associated with the formation of the pacific warm anomaly, or "blob", which reached the coast of southern California in the summer of 2014. During 2014 and 2015 SST was significantly warmer, wind was weaker, and Chl-a 
(a proxy for food availability) was lower. Warmer water temperatures and weak winds may have increased stratification limiting nutrient supply to surface waters and lowering phytoplankton production. The characteristics of larvae at settlement were also consistent with a poor feeding environment. Although larvae at settlement were significantly longer in 2014-15, fish in these years were significantly thinner and showed trends toward slower larval growth and a longer larval duration. This study has implications for understanding future settlement and recruitment of fishes in southern California, as ocean temperatures continue to rise in the face of climate change. 


\section{INTRODUCTION TO THESIS}

\section{Introduction}

\section{West coast bays and estuaries as critical habitat}

Although a great deal is known about the importance of estuaries as critical nursery habitat for fishes on the East and Gulf coasts of the United States (e.g. Able and Fahay 1998), there is little information on estuary use by juvenile fishes of the West coast (but see Allen et al. 2006). In California, this is particularly important as California has experienced a greater than $80 \%$ loss in coastal wetlands (California State Coastal Conservancy 1989) and growing human populations continue to modify the coastal zone. To date, most research on juvenile fishes from west coast estuaries has focused on California halibut (Paralichthys californicus) where studies have shown estuarine nursery use is very low $(3 \%)$ relative to bays $(65 \%)$ and exposed coasts $(31 \%$, Fodrie and Levin 2008). Although west coast estuaries may not represent critical nursery habitat for coastal species such as $P$. californicus, it is important to document the use of estuaries by other species such as newly settled spotted sand bass, Paralabrax maculatofasciatus. Spotted sand bass are primarily found in calm, shallow, nearshore habitats such as bays and estuaries and will not migrate in the open ocean as adults (Allen et al. 1995).

\section{Spotted Sand Bass}

Spotted sand bass (Paralabrax maculatofasciatus) are a recreationally important fish in Southern California typically found from Santa Monica Bay, CA in the north to Mazatlan, Mexico in the south (Allen et al. 1995). There are three major Gulf of California populations that are genetically alike but differ from three Pacific populations (Tranah 
and Allen 1999). Of the Pacific groups, the northernmost population near San Diego is genetically unique from populations near the middle and southern end of the Baja peninsula (Tranah and Allen 1999). Individuals up to 14 years old have been caught, but the average reported maximum age is 10 years (Allen et al. 1995). The majority of the spotted sand bass diet is made up of benthic organisms such as brachyuran crabs (e.g. Hemigrapsus sp., Pachygrapsus sp.), bivalve mollusks (e.g. Tagelus sp., Laevicardium sp.) and amphipods, with larger spotted sand bass also consuming bony fishes such as gobies (Gobiidae) and more pelagic species such as northern anchovies (Engraulis mordax, Love 2011). Females generally reach maturity within the first year of life, at an average standard length (SL) of $155 \mathrm{~mm}$. Males mature after approximately 1.4 years at an average of $180 \mathrm{~mm} \mathrm{SL} \mathrm{(Allen} \mathrm{1985).} \mathrm{Spotted} \mathrm{sand} \mathrm{bass} \mathrm{spawn} \mathrm{in} \mathrm{the} \mathrm{summer} \mathrm{(Allen} \mathrm{et}$ al. 1995) and are capable of spawning multiple times throughout the season (Quast 1968, Oda et al. 1993). Miller and Allen (2006) found that mean egg production was significantly correlated with mean water temperature for each month, with the highest egg production (> $70 \mathrm{ml}$ eggs/day total) occurring during July when the water was warmest during the study. August was the second most productive month, after which egg production steadily decreased and remained relatively low ( $>5 \mathrm{ml}$ eggs/day total) through October.

Pelagic larval duration (PLD) for spotted sand bass is thought to be approximately one lunar month (28 d) with size at settlement near $10 \mathrm{~mm} \mathrm{SL} \mathrm{(Allen} \mathrm{and} \mathrm{Block} \mathrm{2012).} \mathrm{After}$ development offshore, larval spotted sand bass settle to bays and estuaries that contain structured habitats such as eelgrass, surfgrass, and rock relief (Fitch and Lavenberg 1975). It has been hypothesized that southern California populations of $P$. maculatofasciatus may undergo cycles of limited nearshore recruitment in years when 
oceanographic conditions do not favor larval development, which can lead to multi-year gaps in age structure (Allen at al. 1995). These cycles of low recruitment may be due in part to reduced prey availability, as seen in other species with variable year-class strength such as Gizzard Shad, Dorosoma cepedianum (Willis 1987).

The ability of larvae to feed effectively is particularly important because larvae have high metabolic rates and low energy reserves (Fuiman 2002). Laboratory studies of $P$. maculatofasciatus larvae suggest the endogenous feeding period is 2 days, after which they are capable of eating small plankton such as rotifers (e.g. Peña and Dumas 2005). After day 13 , they are able to consume Artemia nauplii and copepods, and can typically move on to fully grown Artemia at 20 days. The transition to Artemia is marked by the activation of acid protease activity at day 12 and other digestive enzymes completely develop by day 18 which indicate maturation of the digestive system (Alvarez-González et al. 2008). As they continue to develop, larger larval prey can be added to their diet including yolk-sac larvae of the same species (Alvarez-Gonzalez et al. 2001). After 40 days, larvae and juveniles can feed on the flesh of other fish such as northern anchovy (Engraulis mordax, Miller and Allen 2006).

After only a few days without food, the larvae of some fish species are unable to survive, at which time they reach a "point of no return" (Eldredge et al. 1981, McGurk 1984, Rana 1985). Laboratory studies of P. maculatofasciatus suggest that when denied food for 1 or 2 days following the endogenous period, they showed high recovery and grew at rates similar to larvae that began feeding immediately (Peña and Dumas 2005). After 12 days, there were no significant differences in size or development of larvae fed after 0,1 or 2 days post hatch. Similar recovery has been observed in grunion (Leuresthes tenuis, May 1971) and striped bass (Morone saxatilis, Rogers and Westin 
1981). Although feeding and ingestion in P. maculatofasciatus occurred after 3 days denied food, larvae were unable to effectively digest prey and mortality was high. All larvae denied food for 4 and 5 days after hatching died due to starvation, identifying it as a point of no return (Peña and Dumas 2005).

Feeding in spotted sand bass larvae is affected by prey density. A study by Peña et al. (2004) examined feeding incidence when rotifer densities were set to 5, 10 and 15/ml. There were significantly fewer successfully feeding larvae at 5 rotifers $/ \mathrm{ml}$, but no difference between 10 and 15/ml. Competition also affects feeding success and growth, as larvae raised at lower densities (50 and 100 larvae/L) had the higher mean standard length and specific growth rates compared with higher densities (150 and 200 larvae/L, Alvarez-González et al. 2001).

\section{Chlorophyll and food availability}

Chlorophyll concentration is a general indicator of the trophic condition of an ecosystem, and can be quickly estimated over large areas using fluorometric instruments or satellites (Hirst and Bunker 2003, Woodson et al. 2012). As a proxy for phytoplankton abundance, increased chlorophyll concentrations likely mean higher food availability for zooplankton and consequently larval fishes. Sufficient densities of zooplankton prey are critical to larval fish growth (Werner and Blaxter 1980, Mills et al. 1989, Papoulias and Minckley 1992) and survival (Kashuba and Matthews 1984, Hart and Werner 1987). Welker et al. (1994) found that larval growth rates of both gizzard shad (Dorosoma cepedianum) and bluegill (Lepomis macrochirus) tended to be higher early in the season, when zooplankton abundance was high, and decreased as prey populations declined. Larval fishes are expected to feed on small zooplankton such as 
rotifers, copepod nauplii, copepodites, and mature copepods (Letcher et al. 1996).

Significant positive relationships between chlorophyll a concentration and growth/fecundity of many copepod species have been reported in environments including polar regions (e.g. Scotia Sea, Shreeve et al. 2002), temperate areas (e.g. Kattegat, Denmark; Kiørboe and Nielsen 1994), tropical waters (e.g. Jamaica, Hopcroft and Roff 1998), and in shallow estuaries (e.g. San Juan Island, Washington state; Landry 1978). In parts of the ocean such as the temperate North Atlantic, zooplankton populations often show a delayed rise of approximately $1-2$ months after a phytoplankton bloom (Nybakken and Bertness 2004). However in the Pacific, constant grazing pressure from zooplankton typically prevents any significant phytoplankton blooms and both populations fluctuate simultaneously (Nybakken and Bertness 2004). Blackburn et al. (1970) detected no lag between seasonal heights of phytoplankton and zooplankton populations in the eastern tropical Pacific. Therefore, it is reasonable to assume that higher chlorophyll levels indicate higher food availability for larval fishes and may be related to faster growth, higher condition, and larger size-at-age.

\section{Settlement}

The majority of marine populations are open and depend on new recruits in the form of larvae or juveniles from the plankton (Caley et al. 1996). Spotted sand bass, like many marine organisms have a complex life history beginning with a pelagic larval phase that transitions or 'settles' to benthic juvenile and adult habitats (Jones et al. 1999, Almany et al. 2007). Settlement may serve as a proxy for larval production when coupled with known oceanographic conditions (Laidig et al. 2007; Caselle et al. 2010a), or at a minimum, may reflect the variable abiotic and biotic environment experienced by larvae. Although future population strength is ultimately determined by both pre- and 
post-settlement processes (Hixon and Webster 2002, Anderson 2007) many studies have found that the number of larvae that reach the juvenile transition is critical to understand population fluctuations (e.g. Sebastes sp., Caselle et al. 2010b).

Settlement rates of marine organisms fluctuate, which is due in part to the high and variable larval mortality rates that can average $20 \%$ per day and may reach $>99 \%$ over the entire larval period (Houde 1996, 2002). Probability of mortality may be related to a variety of factors including larval traits such as length, age and condition which in turn are influenced by environmental factors, such as temperature and food availability (Alford and Harris 1988, Bertness and Gaines 1993, McCormick and Molony 1995). Anomalously warm sea surface conditions have been linked to decline in rockfish in Southeast Farallon Island (Warzybok and Bradley 2011) as well as in Trinidad Bay, California (Jones 2012).

Documenting individual trait variability at settlement is particularly important as it reflects the influence of environmental conditions experienced by larvae and may help predict juvenile survival and the strength of future cohorts. The growth-mortality hypothesis (Anderson 1988) summarizes the possibility that traits expressed in the larval stage may affect probability of surviving to subsequent stages. This hypothesis covers three mechanisms by which larvae may increase survivorship: 1) increased size, 2) faster growth rate, and 3) shorter larval duration. First, if mortality is size-dependent, then larger individuals of a given age will have a lower probability of mortality than smaller individuals of the same age (e.g. Leggett and Deblois 1994). Larger individuals may be able to detect and respond to predators more effectively (Bailey and Houde 1989, Fuiman and Magurran 1994). Second, if the probability of mortality is lower for larger individuals, then larvae with faster growth may gain an advantage with respect to 
avoiding predation, obtaining food, and the ability to withstand starvation (Miller et al. 1988, Bailey and Houde 1989). Selective mortality of smaller and slower-growing larvae has been observed in two snapper species (Ocyurus chrysurus, Lutjanus synagris) which reduced variability in size at settlement (D'Alessandro et al. 2013). Finally, larvae with a shorter larval duration may avoid high mortality in this stage and have a higher chance of survival to become a juvenile (Anderson 1988, Cushing 1990). Therefore, extension of the larval period (delayed settlement) caused by slower developmental rates or through physical processes such as currents, storms, and upwelling events that prevent larvae from reaching suitable settlement may increase mortality (Houde 1987, Leis and McCormick 2002, Cowen 2002, Schmitt and Holbrook 2002).

\section{Physical factors influencing settlement}

Lunar phase is often associated with settlement patterns of marine organisms. For example, settlement near the new moon has been found for many species that utilize estuaries as juvenile nurseries: e.g. flounder, Paralichthys and penaeid shrimps (Penaeus duorarum, Williams and Deubler 1968) and Atlantic croaker (Micropogonias undulates, Hettler and Chester 1990). Moving into the estuary during the new moon when current velocities are higher may be a strategy to maximize ingress towards nursery habitats (Anderson et al. 2007). In coral reef fishes, stronger settlement near the new moon has been observed for blue chromis (Chromis cyanea, Anderson et al. 2007) and bicolor damselfish (Stegastes partitus, Roberston et al. 1987) and has been hypothesized as a strategy to utilize the darker night to minimize predation by visual nocturnal feeders. Other species such as the Yellowfin bream (Acanthopagrus australis) also settle in estuary habitats near the time of new moon, however it is unclear if the moon cues 
settlement, or if the peak larval input reflects the timing of spawning (Pollock et al. 1983).

Lunar phase may also be associated with a variety of physical mechanisms that can transport larvae such as internal waves. Internal waves are created during times of low tidal amplitude when there is a shallow thermocline (Cairns 1968, Kingsford and Choat 1986, Shanks 1988), a common occurrence in spring and summer in the Southern California Bight (Pineda 1994, Pineda 1995). Internal waves in nearshore environments produce two potential transport mechanisms for pelagic larvae that may explain variation in settlement rates: surface slicks and tidal bores. Surface slicks are produced as internal waves move toward the shore, when downwelling from the rotary currents causes water to form a convergent zone where larvae may aggregate (Shanks 1983, Kingsford and Choat 1986). Surface slicks may form at wind velocities below 6-7 m/s (Kingsford 1990), and are dispersed with stronger winds (Shanks and Wright 1987). Organisms that remain in the surface slick by swimming or other behaviors (Shanks 1985) will aggregate and be transported to shore (Shanks 1983, Shanks 1995). Densities of ichthyoplankton and zooplankton have been reported up to 40 times higher in surface slicks relative to adjacent surface waters (Kingsford and Choat 1986, Shanks 1988).

Internal tidal bores form during higher amplitude tides when flow is strongest and may transport larvae in pulses (Shanks 1983, Pineda 1991, Pineda 1999). During spring tides, large internal bores create near-bottom onshore flow and push surface waters offshore (Winant and Bratkovich 1981). Internal tidal bores are turbulent and can disrupt and weaken the thermocline by introducing subsurface cold water near the surface (Cairns 1968). The presence of tidal bores is marked by diurnal or semidiurnal decreases in 
surface temperature (up to $5.4^{\circ} \mathrm{C}$ ) that last for 2-9 days (Pineda 1991, Pineda 1995, Leichter et al. 1996).

Additional physical processes may affect dispersal and settlement of pelagic larvae in many ways, including: 1) retention due to features such as eddies (Milicich 1994; Vargas et al. 1998; Logerwell and Smith 2001), 2) larval drift with prevailing currents (Hutchins and Pearce 1994; Milicich 1994), 3) concentration or supply of food sources (Zimmerman and Kremer 1984; Witman et al. 1993; Druce and Kingsford 1995; Woodson et al. 2012), and 4) the impact of upwelling (Roughgarden et al. 1991). Upwelling occurs along the west coast of the United States primarily in spring and summer when strong winds from the north and northwest move surface waters offshore, which are then replaced with cooler, nutrient-rich water from depth. During upwelling events, increased phytoplankton growth supports a trophic pyramid that includes zooplankton and many fish species (Ryther 1969). A twenty-eight year study using bird diets to monitor juvenile fish recruitment to the Farallon Islands determined that the abundance of rockfish increased with greater upwelling intensities. However, it is unclear whether upwelling was the sole factor due to an unstable adult population, and variability in fishing during the study period (Miller and Snydeman 2004). In the Bay of Biscay, weak winds produced upwelling conditions with low turbulence that significantly increased the recruitment of local anchovy (Engraulis encrasicholus) due to enhancement of productivity and food supply (Borja et al. 1996). In contrast, another study found larval surfclam (Spisula solidissima) concentrations were low during upwelling, and higher during and after downwelling. Pulses of highest larval surfclam concentrations coincided with the initial arrival of downwelled warm water, with which the larvae are known to closely associate (Ma 2005). 
Upwelling events may also be associated with ocean fronts that develop between the gradient of nearshore cold water and warmer offshore waters. These fronts are known as regions of increased abundance and diversity of taxa from many trophic levels (Wolanski and Hamner 1988, Ainley et al. 2009, Belkin et al. 2009) including fish species such as rockfish (Bjorkstedt et al. 2002, Landaeta and Castro 2006, Woodson et al. 2012). Fronts may act as barriers to cross-shelf transport, as has been shown for mussels and barnacles on the Oregon coast (McCulloch and Shanks 2003, Shanks et al. 2003). Upwelling fronts have also been associated with enhanced intertidal invertebrate recruitment as winds periodically relax and fronts move shoreward (Roughgarden et al. 1991). Areas of high front activity, where recruitment of species (e.g. rockfish) is typically less variable and generally higher, are thought to be more resilient and sustainable compared to regions with fewer fronts (Woodson et al. 2012).

\section{Southern California Bight oceanography}

In the central region of the Southern California Bight, pressure gradients associated with coastal trapped waves often dominate currents (Hickey 1992, Hickey et al. 2003). Coastal trapped waves in Southern California are caused by winds along the coast of Baja California, Mexico, which generate waves that propagate along the thermocline and up the coast (Lentz and Winant 1986, Pringle and Riser 2003).

At least part of the year the waves force an overturning circulation nearshore, so the remote winds force local upwelling and downwelling. Coastal trapped waves also increase nearshore stratification, which can suppress turbulence and encourage the growth of dinoflagellates and other turbulence-sensitive organisms while reducing the mixing-driven vertical flux of nutrients (Pringle and Riser 2003). Increased stratification 
also increases the phase speed of internal waves and bores, reducing the amount of dissipation they experience across the shelf and increasing their amplitude in the nearshore (Pringle and Brink 1999), and potentially increasing delivery of larvae to the coast (Pineda and Lopez 2002).

\section{Measuring settlement}

Marine ecologists use a variety of methods to quantify larval supply and settlement of fish. Each method comes with its own advantages and limitations. Towed plankton nets generate density estimates of pelagic larvae and juveniles (e.g. Choat et al. 1993, Larson et al. 1994), but may not accurately sample the spatially and temporally patchy distributions of pre-settled fishes due to relatively short duration of sampling. Towed nets also eliminate the possibility to confirm whether a fish has undergone settlement by finding it associated with a natural or artificial substrate (Ammann 2004).

Other collection methods are meant to occupy the same area and continuously sample for longer periods of time. Multiple fixed nets, such as channel nets (e.g. Thorrold et al. 1994, Kingsford 2001), can sample many areas simultaneously, but rely on currents strong enough to force larvae into them. Light traps have been very successful at collecting settlement stage coral reef fishes (e.g. Pomacentrus amboinensis, Ferrari et al. 2012). Light traps are anchored cylindrical nets that remain stationary in the water column. Conical openings in the nets allow plankton to enter while making it difficult for them to exit. One or more lights are suspended within the net to attract larvae. While successful at collecting larvae, these traps are only effective at sampling phototaxic species at night (Ammann 2004). Channel nets and light traps only serve as relative 
measures of larval abundance, as predation may be enhanced within the net prior to collection.

Underwater visual surveys can provide estimates of density or relative abundances of many newly settled fishes (e.g. Jones 1990, Carr 1991, Levin 1994), but the observers must deal with physical factors (e.g. turbidity, surge) that may limit accuracy of observations (Ebeling and Hixon 1991). During these observations it can be difficult to determine age of settled fishes, as they are often cryptic and mortality may occur between surveys.

An alternative method to assessing settlement is the use of standardized units of artificial substrate that attract ready-to-settle reef fish. Examples of portable artificial substrates used to measure recruitment of juveniles include tufts of rope fibers used for anguilid glass eels (Silberschneider et al. 2001), artificial seagrass units for crustaceans and post-larval fishes (Hair et al. 1994, Kenyon et al. 1999), units of coiled wire for postlarval coral reef fishes (Schroeder 1987), and units of folded plastic grid for a temperate reef serranid (Findlay and Allen 2002, Steele et al. 2002). Artificial substrates rely on the thigmotaxic behavior (i.e. affinity for physical structure) of many fishes. Artificial substrates can be used in a manner that overcomes some of the limitations of the methods listed above. For example, when visually surveying recruits in a natural habitat, variation in available habitat can strongly influence estimates of settlement, especially in dynamic macroalgal-dominated temperate reef regions (Levin 1993, Anderson 1994, Carr 1994). However, the number of artificial substrates can be easily controlled and standardized, streamlining the monitoring process. Post-settlement mortality due to predation may be reduced on artificial substrates because the units can be placed away from natural reefs and associated resident predators (Connell 1997) and because the 
structurally complex substrate may provide juvenile fish with shelter from more mobile predators (Hixon and Carr 1997). Artificial substrates are continuously available to sample for potential settlers at various sites, unlike individual towed net samples which are spatially and temporally limited. Therefore, artificial substrates may better account for variable larval distributions spatially and over time (Gaines and Bertness 1993).

Furthermore, artificial substrates are more economical, simpler to build and maintain, and can be deployed for longer intervals of sampling. For certain fish species in temperate regions, substrate-based collectors were found to be more efficient than light traps in collecting settling larvae (e.g. Paralabrax clathratus, Steele et al. 2002). Finally, units are portable and lightweight so they can be removed from the water to be processed without loss of recruits. In this study, we used a modification of the Standard Monitoring Units for the Recruitment of Fishes (SMURFs) design (Ammann 2004) to examine settlement of $P$. maculatofasciatus in Mission Bay, San Diego CA. 


\section{Questions and Hypotheses}

1. Is there interannual or intra-annual variation in settlement of spotted sand bass in Mission Bay?

$\mathrm{H}_{0}$ : $\quad$ Settlement of spotted sand bass in Mission Bay will not vary significantly among years or within years.

2. Is variation in settlement of spotted sand bass related to environmental conditions?

$\mathrm{H}_{0}$ : $\quad$ Settlement of spotted sand bass does not vary significantly in relation to changes in environmental conditions.

3. Is variation in settlement of spotted sand bass related to larval traits?

$\mathrm{H}_{0}$ : Settlement of spotted sand bass does not vary significantly in relation to differences in larval traits. 


\section{LITERATURE CITED FOR INTRODUCTION}

Able KW and Fahay MP (1998) The first year in the life of estuarine fishes in the middle Atlantic bight. Rutgers University Press, New Brunswick, N. J.

Ainley DG, Dugger KD, Ford RG, Pierce SD, Reese DC, Brodeur RD, Tynan CT, and Barth JA (2009) Association of predators and prey at frontal features in the California Current: Competition, facilitation, and co-occurrence. Marine Ecology Progress Series 389:271294

Alford RA and Harris RN (1988) Effects of larval growth history on anuran metamorphosis. American Naturalist 131:91-106

Allen LG (1985) A habitat analysis of the nearshore marine fishes from Southern California. Bulletin of the Southern California Academy of Sciences 84:233-155

Allen LG, Yoklavich MM, Caillet GM, and Horn MH (2006) the ecology of marine fishes, California and adjacent waters. Bays and Estuaries. University of California Press, Los Angeles, pp. 119-148

Allen LG, Block HE (2012) Planktonic larval duration, settlement, and growth rates of the young-of-the-year of two sand basses (Paralabrax nebulifer and $P$. maculatofasciatus: fam. Serranidae) from Southern California. Bulletin, Southern California Academy of Sciences 111:15-21

Allen LG, Hovey TE, Love MS, Smith JTW (1995) The life history of the spotted sand bass (Paralabrax maculatofasciatus) within the Southern California Bight. CalCOFI Rep 36:193-203

Almany GR, Berumen ML, Thorrold SR, Planes S, and Jones GP (2007) Local replenishment of coral reef populations in a marine reserve. Science 316:742-744

Alvarez-González CA, Ortíz-Galindo JL, Dumas S, Martínez-Díaz SF, Hernández-Ceballos DE, Alamo TG, Moreno-Legorreta M, and Peña-Martínez R (2001) Effect of stocking density on the growth and survival of spotted sand bass (Paralabrax maculatofasciutus) larvae in a closed recirculating system. Journal of the World Aquaculture Society 32:130-137

Alvarez-González CA, Moyano-López FJ, Civera-Cerecedo R, Carrasco-Chávez V, OrtízGalindo JL, and Dumas S (2008) Development of digestive enzyme activity in larvae of spotted sand bass Paralabrax maculatofasciatus 1. Electrophoretic analysis. Fish Physiology and Biochemistry 34:373-384

Ammann AJ (2004) SMURFs: Standard monitoring units for the recruitment of temperate reef fishes. Journal of Experimental Marine Biology and Ecology 299:135-154 
Anderson TW (1994) Role of macroalgal structure in the distribution and abundance of a temperate reef fish. Marine Ecology Progress Series 113:279-290

Anderson JT (1988) A review of size dependent survival during pre-recruit stages of fishes in relation to recruitment. Journal of Northwest Atlantic Fishery Science 8:55-66

Anderson TW, Carr MH, Hixon MA (2007) Patterns and mechanisms of variable settlement and recruitment of a coral reef damselfish, Chromis cyanea. Marine Ecology Progress Series 350:109-116

Bailey KM and Houde ED (1989) Predation on eggs and larvae of marine fishes and the recruitment problem. Advances in Marine Biology 25:1-83

Bertness MD and Gaines SD (1993) Larval dispersal and local adaptation in acorn barnacles. Evolution 47:316-320

Bjorkstedt EP, Rosenfeld LK, Grantham BA, Shkedy Y, and Roughgarden J (2002) Distributions of larval rockfish Sebastes spp. across nearshore fronts in an upwelling region. Marine Ecology Progress Series 242:215-228

Blackburn M, Laurs RM, Owen RW, and Zeitschel B (1970) Seasonal and areal changes in standing stocks of phytoplankton, zooplankton and micronekton in the eastern tropical Pacific. Marine Biology 7:14-31

Borja Á, Uriarte A, Valencia V, Motos L, and Uriarte A (1996) Relationships between anchovy (Engraulis encrasicolus L.) recruitment and the environment in the Bay of Biscay. Scientia Marina 60:179-192

Cairns JL (1968) Thermocline strength fluctuations in coastal waters. Journal of Geophysical Research 73:2591-2595

Caley MJ, Carr MH, Hixon MA, Hughes TP, and Menge BA (1996) Recruitment and the local dynamics of open marine populations. Annual Review of Ecology Evolution and Systematics 27:477-500

California State Coastal Conservancy (1989) The coastal wetlands of San Diego County. Warren Walker Press Inc., Sacramento, California. 99 pgs.

Carr MH (1991) Habitat selection and recruitment of an assemblage of temperate zone reef fishes. Journal of Experimental Marine Biology and Ecology 146:113-137

Carr MH (1994) Effects of macroalgal dynamics on recruitment of a temperate reef fish. Ecology 75:1320-1333

Caselle JE, Kinlan BP, and Warner RR (2010a) Temporal and spatial scales of influence on nearshore fish settlement in the southern California Bight. Bulletin of Marine Science 86:355-385 
Caselle JE, Carr MH, Wilson JR, and Wendt DE (2010b) Can we predict interannual and regional variation in delivery of pelagic juveniles to nearshore populations of rockfishes (genus Sebastes) using simple proxies of ocean conditions? California Cooperative Oceanic Fisheries Investigations 51:91-105

Choat JH, Doherty PJ, Kerrigan BA, and Leis JM (1993) A comparison of towed nets purse seine and light aggregation devices for sampling larvae and pelagic juveniles of coral reef fishes. Fisheries Bulletin 91:195-209

Connell SD (1997) The relationship between large predatory fish and recruitment and mortality of juvenile coral reef-fish on artificial reefs. Journal of Experimental Marine Biology and Ecology 209:261-278

Cowen RK (2002) Larval dispersal and retention and consequences for population connectivity. Coral reef fishes: dynamics and diversity in a complex ecosystem.

Academic Press, San Diego, CA, p 149-170

Cushing DH (1990) Plankton production and year-class strength in fish populations: an update of the match/mismatch hypothesis. Advances in Marine Biology 26:142-155

D’Alessandro EK, Sponaugle S, and Cowen RK (2013) Selective mortality during the larval and juvenile stages of snappers (Lutjanidae) and great barracuda Sphyraena barracuda. Marine Ecology Progress Series 474:227-242

Druce BE and Kingsford MJ (1995) An experimental investigation on the fishes associated with drifting objects in coastal waters of temperate Australia. Bulletin of Marine Science 57:378-392

Ebeling AW, and Hixon MA (1991) Tropical and temperate reef fishes: comparison of community structures. The Ecology of Fishes on Coral Reefs. Academic Press, San Diego, p. 509-563

Eldredge MB, Whipple JA, Eng D, Bowers MJ, and Jarvis BM (1981) Effects of food and feeding factors on laboratory-reared striped bass larvae. Transactions of the American Fisheries Society 110:111-120

Ferrari MCO, McCormick MI, Munday PL, Meekan MG, Dixson DL, Lönnstedt O, and Chivers DP (2012) Effects of ocean acidification on visual risk assessment in coral reef fishes. Functional Ecology 26:553-558

Findlay AM and Allen LG (2002) Temporal patterns of settlement in the temperate reef fish Paralabrax clathratus. Marine Ecology Progress Series 238:237-248

Fitch JE and Lavenberg RJ (1975) Tidepool and nearshore fishes of California. University of California Press, p. 156

Fodrie FJ and Levin LA (2008) Linking juvenile habitat utilization to population dynamics of California halibut. Limnology and Oceanography 53:799-812 
Fuiman LA (2002) Special considerations of fish eggs and larvae. Fishery science: the unique contributions of early life stages. Blackwell Science, Oxford, UK, p. 1-32

Fuiman LA and Magurran AE (1994) Development of predator defenses in fishes. Reviews in Fish Biology and Fisheries 4:145-183

Gaines SD and Bertness M (1993) The dynamics of juvenile dispersal: why field ecologists must integrate. Ecology 74:2430-2435

Hair CA, Bell JD, and Kingsford MJ (1994) Effects of position in the water column, vertical movement and shade on settlement of fish to artificial habitats. Bulletin of Marine Science 55:434-444

Hart TF and Werner RG (1987) Effects of prey density on growth and survival of white sucker, Catostornus commersoni and pumpkinseed Lepomis gibbosus larvae.

Environmental Biology of Fishes 18:41-50

Hettler WF and Chester AJ (1990) Temporal distribution of ichthyoplankton near Beaufort Inlet, North Carolina. Marine Ecology Progress Series 68:157-168

Hickey BM (1992) Circulation over the Santa Monica-San Pedro Basin and shelf. Progress in Oceanography 30:37-116

Hickey BM, Dobbins EL, and Allen SE (2003) Local and remote forcing of currents and temperature in the central Southern California Bight. Journal of Geophysical Research 108:1-26

Hirst AG and Bunker AJ (2003) Growth of marine planktonic copepods: Global rates and patterns in relation to chlorophyll a, temperature, and body weight. Limnology and Oceanography 48:1988-2010

Hixon MA and Carr MH (1997) Synergistic predation, density dependence, and population regulation in marine fish. Science 277:946-949

Hixon MA, Webster MS (2002) Density dependence in marine fishes: coral reef populations as model systems. Coral Reef Fish p. 303-325

Hopcroft RR and Roff JC (1998) Zooplankton growth rates: The influence of female size and resources on egg production of tropical marine copepods. Marine Biology 132:7986

Houde ED (1987) Fish early life dynamics and recruitment variability. American Fisheries Society Symposium 2:17-29

Houde ED (1996) Evaluating stage-specific survival during the early life of fish. Survival strategies in early life stages of marine resources. A. A. Balkema, Rotterdam, The Netherlands, p. 51-66

Houde ED (2002) Mortality. Fishery science: the unique contributions of early life stages. Blackwell Science, Oxford, UK, p. 64-87 
Hutchins JB and Pearce AF (1994) Influence of the Leeuwin Current on recruitment of tropical reef fishes at Rottnest Island, Western Australia. Bulletin of Marine Science 54:245-255

Jones GP (1990) The importance of recruitment to the dynamics of a coral reef fish population. Ecology 71:1691-1698

Jones GP, Milicich MJ, Emslie MJ, and Lunow C (1999) Self-recruitment in a coral reef fish population. Nature 402:802-804

Jones M (2012) Deployment of Standard Monitoring Units for the Recruitment of Fishes, SMURFs, in Trinidad Bay, California. Thesis awaiting publication.

Kashuba SA and Matthews WJ (1984) Physical condition of larval shad during springsummer in a southwestern reservoir. Transactions of the American Fisheries Society 113:199-204

Kenyon RA, Haywood MDE, Heales DS, Loneragan NR, Pendrey RC, and Vance DJ (1999) Abundance of fish and crustacean postlarvae on portable artificial seagrass units: daily sampling provides quantitative estimates of the settlement of new recruits. Journal of Experimental Marine Biology and Ecology 232:197-216

Kingsford MJ and Choat JH (1986) Influence of surface slicks on the distribution and onshore movement of small fish. Marine Biology 91:161-171

Kingsford MJ (1990) Linear oceanographic features: a focus for research on recruitment processes. Australian Journal of Ecology 15:391-401

Kingsford MJ (2001) Diel patterns of abundance of presettlement reef fishes and pelagic larvae on a coral reef. Marine Biology 138:853-867

Kiørboe T and Nielsen TG (1994) Regulation of zooplankton biomass and production in a temperate, coastal ecosystem. Limnology and Oceanography 39:493-507

Laidig TE, Chess JR, and Howard DF (2007) Relationship between abundance of juvenile rockfishes (Sebastes spp.) and environmental variables documented off northern California and potential mechanisms for the covariation. Fisheries Bulletin 105:39-48

Landaeta MF and Castro LR (2006) Larval distribution and growth of the rockfish, Sebastes capensis (Sebastidae, Pisces), in the fjords of southern Chile. ICES Journal of Marine Science 63:714-724

Landry MR (1978) Population dynamics and production of a planktonic marine copepod, Acartia clausii, in a small temperate lagoon on San Juan Island, Washington.

Internationale Revue der gesamten Hydrobiologie und Hydrographie 63:77-119

Larson R, Lenarz W, and Ralston S (1994) The distribution of pelagic juvenile rockfish of the genus Sebastes in the upwelling region off central California. California Cooperative Oceanic Fisheries Investigations 35:175-211 
Leggett WC and DeBlois E (1994) Recruitment in marine fishes: is it regulated by starvation and predation in the egg and larval stages? Netherlands Journal of Sea Research 32:119-134

Leichter JJ, Wing SR, Miller SL, and Denny MW (1996) Pulsed delivery of subthermocline water to Conch Reef (Florida Keys) by internal tidal bores. Limnology and Oceanography 41:1490-1501

Leis JM and McCormick MI (2002) The biology, behavior, and ecology of the pelagic, larval stage of coral reef fishes. Academic Press, San Diego, CA, p. 171-199

Lentz SJ and Winant CD (1986) Subintertidal currents on the Southern California shelf. Journal of Physical Oceanography 16:1737-1749

Letcher BH, Rice JA, Crowder LB, and Rose KA (1996) Variability in survival of larval fish: disentangling components with a generalized individual-based model. Canadian Journal of Fisheries and Aquatic Science 53:787-801

Levin PS (1993) Habitat structure, conspecific presence and spatial variation in the recruitment of a temperate reef fish. Oecologia 94:176-185

Levin PS (1994) Fine-scale temporal variation in recruitment of a temperate demersal fish -the importance of settlement versus postsettlement loss. Oecologia 97:124-133

Logerwell E and Smith P (2001) Mesoscale eddies and survival of late stage Pacific sardine (Sardinops sagax) larvae. Fisheries Oceanography 10:13-25

Love MS (2011) Certainly more than you want to know about fishes of the Pacific coast. Really Big Press, Santa Barbara, CA

Ma $\mathrm{H}$ (2005) Spatial and temporal variation in surfclam (Spisula solidissima) larval supply and settlement on the New Jersey inner shelf during summer upwelling and downwelling. Estuarine, Coastal and Shelf Science 62:41-53

McCormick MI and Molony BW (1995) Influence of water temperature during the larval stage on size, age and body condition of a tropical reef fish at settlement. Marine Ecology Progress Series 118:59-68

McCulloch A and Shanks AL (2003) Topographically generated fronts, very nearshore oceanography and the distribution and settlement of mussel larvae and barnacle cyprids. Journal of Plankton Research 25:1427-1439

McGurk MD (1984) Effects of delayed feeding and temperature on the age of irreversible starvation and on the rates of growth and mortality of Pacific herring larvae. Marine Biology 84:13-26

Milicich MJ (1994) Dynamic coupling of reef fish replenishment and oceanographic processes. Marine Ecology Progress Series 110:135-144 
Miller AK and Sydeman WJ (2004) Rockfish response to low frequency ocean climate change as revealed by the diet of a marine bird over multiple time scales. Marine Ecology Progress Series 281:207-216

Miller EF and Allen LG (2006) Captive breeding of spotted sand bass, Paralabrax maculatofasciatus, in southern California. California Fish and Game 92:98-105

Miller TJ, Crowder LB, Rice JA, and Marschall EA (1988) Larval size and recruitment mechanisms in fishes: toward a conceptual framework. Canadian Journal of Fisheries and Aquatic Science 45:1657-1670

Mills EL, Sherman R, and Robson DS (1989) Effect of zooplankton abundance and body size on growth of age-0 yellow perch (Perca flavescens) in Oneida Lake, New York, 19751986. Canadian Journal of Fisheries and Aquatic Sciences 46:880-886

Nybakken JW and Bertness MD (2004) Marine biology: and ecological approach. Benjamin Cummings, $6^{\text {th }}$ Edition p. 42-102

Oda DL, Lavenberg RJ, and Rounds JM (1993) Reproductive biology of three California species of Paralabrax (Pisces: Serranidae). California Cooperative Oceanic Fisheries Investigations 34:122-132

Papoulias D and Minckley WL (1992) Effects of food availability on survival and growth of larval razorback suckers in ponds. Transactions of the American Fisheries Society 121:340-355

Peña R, Dumas S, Saldivar-Lucio R, García G, Trasviña A, and Hernández-Ceballos D (2004) The effect of light intensity on first feeding of the spotted sand bass Paralabrax maculatofasciatus (Steindachner) larvae. Aquaculture Research 35:345-349

Peña R and Dumas S (2005) Effect of delayed first feeding on development and feeding ability of Paralabrax maculatofasciatus larvae. Journal of Fish Biology 67:640-651

Pineda J (1991) Predictable upwelling and the shoreward transport of plankton larvae by internal tidal bores. Science 253:548-551

Pineda J (1994) Internal tidal bores in the nearshore: Warm water fronts, seaward gravity currents and the onshore transport of neustonic larvae. Journal of Marine Research 52:427-458

Pineda J (1995) An internal tidal bore regime at nearshore stations along western U.S.A.: Predictable upwelling with the lunar cycle. Continental Shelf Research 15:1023-1041

Pineda J (1999) Circulation and larval distribution in internal tidal bore warm fronts. Limnology and Oceanography 44:1400-1414

Pineda J and Lopez M (2002) Temperature, stratification and barnacle larval settlement in two Californian sites. Continental Shelf Research 22:1183-1198 
Pollock BR, Weng H, and Morton RM (1983) The seasonal occurrence of post larval stages of yellowfin bream (Acanthopagrus australis) and some factors affecting their movement into an estuary. Journal of Fisheries Biology 22:409-416

Pringle JM and Brink KH (1999) High-frequency internal waves on a sloping shelf. Journal of Geophysical Research 104:5283-5299

Pringle JM and Riser K (2003) Remotely forced nearshore upwelling in Southern California. Journal of Geophysical Research 108:1-11

Quast JC (1968) Observations on the food and biology of the kelp bass, Paralabrax clathratus, with notes on its sportfishery at San Diego, California. California Fish and Game Fish Bulletin 139:81-108

Rana KJ (1985) Influence of egg size on the growth, onset of feeding, point-of-no-return, and survival of unfed Oreochromis mossambicus fry. Aquaculture 46:119-131

Robertson DR, Green DG, Victor BC (1987) Relations in the lunar periodicities of larval production and settlement by a Caribbean reef fish. Bulletin of Marine Science 41:641

Rogers BA and Westin DT (1981) Laboratory studies on effects of temperature and delayed initial feeding on development of striped bass larvae. Transactions of the American Fisheries Society 110:100-110

Roughgarden J, Pennington JT, Stoner D, Alexander S, and Miller K (1991) Collisions of upwelling fronts with the intertidal zone: The cause of recruitment pulses in barnacle populations of central California. Acta Oecologica 12:35-51

Ryther JH (1969) Photosynthesis and fish production in the sea. Science 166:72-76

Schmitt RJ and Holbrook SJ (2002) Spatial variation in concurrent settlement of three damselfishes: relationships with near-field current flow. Oecologia 131:391-401

Schroeder RE (1987) Effects of patch reef size and isolation on coral reef fish recruitment. Bulletin of Marine Science 41:441-451

Shanks AL (1983) Surface slicks associated with tidally forced internal waves may transport pelagic larvae of benthic invertebrates and fishes shoreward. Marine Ecology Progress Series 13:311-315

Shanks AL (1985) Behavioral basis of internal-wave-induced shoreward transport of megalopae of the crab Pachygrapsus crassipes. Marine Ecology Progress Series 24:289295

Shanks AL (1988) Further support for the hypothesis that internal waves can cause shoreward transport of larval invertebrates and fish. Fishery bulletin 86:703-714

Shanks AL (1995) Orientated swimming by megalopae of several eastern North Pacific crab species and its potential role in their onshore migration. Journal of experimental marine biology and ecology 186:1-16 
Shanks AL, McCulloch A, and Miller J (2003) Topographically generated fronts, very nearshore oceanography and the distribution of larval invertebrates and holoplankters. Journal of Plankton Research 25:1251-1277

Shanks AL and Wright WG (1987) Internal-wave-mediated shoreward transport of cyprids, megalopae, and gammarids and correlated longshore differences in the settling rate of intertidal barnacles. Journal of Experimental Marine Biology and Ecology 114:113

Shreeve RS, Ware P, and Whitehouse MJ (2002) Copepod growth and development around South Georgia: Relationships with temperature, food and krill. Marine Ecology Progress Series 233:169-183

Silberschneider V, Pease BC, and Booth DJ (2001) A novel artificial habitat collection device for studying resettlement patterns in anguillid glass eels. Journal of Fisheries Biology 58:1359-1370

Steele MA, Malone JC, Findlay AM, Carr MH, and Forrester GE. 2002. A simple method for estimating larval supply in reef fishes and a preliminary test of population limitation by larval delivery in the kelp bass, Paralabrax clathratus. Marine Ecology Progress Series 235:195-203

Thorrold SR, Shenker JM, Mojica R, Maddox ED, and Wishinski E (1994) Temporal patterns in the larval supply of summer-recruitment reef fishes to lee stocking island, Bahamas. Marine Ecology Progress Series 112:75-86

Tranah GJ and Allen LG (1999) Morphologic and genetic variation among six populations of the spotted sand bass, Paralabrax maculatofasciatus, from southern California to the upper Sea of Cortez. Bulletin, Southern California Academy of Sciences 98:103-118

Vargas CA, Valenzuela GS, and Arcos DF (1998) Role of oceanographic topographic factors in the retention of hake (Merluccius gayi gayi Guichenot, 1848) larvae in the upwelling system off central-southern Chile. Archive of Fishery and Marine Research 45:201-222

Warzybok PM and Bradley RW (2011) Status of seabirds on Southeast Farallon Island during the 2011 breeding season. United States Fish and Wildlife Service and Point Reyes Bird Observatory Conservation Science, Point Reyes Bird Observatory Contribution \#1836, Petaluma, California.

Welker MT, Pierce CL, and Wahl DH (1994) Growth and survival of larval fishes: roles of competition and zooplankton abundance. Transactions of the American Fisheries Society 123:703-717

Werner RG and Blaxter JHS (1980) Growth and survival of larval herring (Clupea harengus) in relation to prey density. Canadian Journal of Fisheries and Aquatic Sciences 37:1063-1069 
Williams AB and Deubler EE (1968) A ten year study of meroplankton in North Carolina estuaries: assessment of environmental factors and sampling success among bothid flounders and penaeid shrimps. Chesapeake Science 9:27-41

Willis DW (1987) Reproduction and recruitment of gizzard shad in Kansas reservoirs. North American Journal of Fisheries Management 7:71-80

Winant CD and Bratkovich AW (1981) Temperature and currents on the southern California shelf: a description of the variability. Journal of Physical Oceanography 11:7186

Witman JD, Leichter JJ, Genovese SJ, and Brooks DA (1993) Pulsed phytoplankton supply to the rocky subtidal zone: influence of internal waves. Proceedings of the National Academy of Sciences of the USA, 90:1686-1690

Woodson CB, McManus MA, Tyburczy J, Barth JA, Washburn L, Raimondi PT, Menge BA, and Palumbi SR (2012a) Persistent fronts structure connectivity patterns along the Eastern Pacific. Limnology and Oceanography 57:582-596

Woodson CB, McManus MA, Tyburczy JA, Barth JA, Washburn L, Caselle JE, Carr MH, Malone DP, Raimondi PT, Menge BA, and Palumbii SR (2012b) Coastal fronts set recruitment and connectivity patterns across multiple taxa. Limnology and Oceanography 57:582-596

Zimmerman RC, and Kremer JN (1984) Episodic nutrient supply to a kelp forest ecosystem in Southern California. Journal of Marine Research 42:591-604 


\section{INTRODUCTION}

Many marine fishes and invertebrates have a complex life history with pelagic larvae that settle to benthic juvenile/adult habitats (Navarrete et al. 2002, Wing et al. 2003, Wilson et al. 2008, Watson et al. 2010). Although it is widely acknowledged that population strength is determined by both pre- and post-settlement processes (Hixon and Webster 2002, Anderson et al. 2007), various studies have found that the number of larvae that reach settlement is a critical factor contributing to interannual population fluctuations (Wing et al. 2003, Caselle et al. 2010a, Ralston et al. 2013). The number of larvae that survive to settlement may also serve as a proxy for larval production when coupled with known environmental conditions (Laidig et al. 2007, Caselle et al. 2010b), or at a minimum, may reflect the variable abiotic and biotic environment experienced by larvae. Changes in the pelagic environment in addition to predation may contribute to high and variable larval mortality rates which can average $20 \%$ per day and may reach >99\% over the entire larval period (Houde 1996, 2002, Fuiman and Werner 2002, SotoMendoza et al. 2012). Probability of mortality may be related to a variety of factors including larval traits such as length, age and physiological condition which in turn are influenced by environmental factors, such as temperature and food availability (Alford and Harris 1988, Bertness and Gaines 1993, McCormick and Molony 1995, Searcy and Sponaugle 2001, Houde 2008, Paulsen et al. 2014).

Documenting individual trait variability at settlement is particularly important as it reflects the influence of environmental conditions experienced by larvae and may help predict juvenile survival and the strength of future cohorts (Sponaugle et al. 2006, Paulsen et al. 2014). The growth-mortality hypothesis (Anderson 1988) summarizes the 
possibility that traits expressed in the larval stage may affect probability of surviving to subsequent stages. This hypothesis covers three mechanisms by which larval traits may increase survivorship: 1) increased size, 2) faster growth rate, and 3) shorter larval duration. First, if mortality is size-dependent, then larger individuals of a given age will have a lower probability of mortality than smaller individuals of the same age (e.g. Leggett and DeBlois 1994). Larger individuals may be able to detect and respond to predators more effectively (Bailey and Houde 1989, Fuiman and Magurran 1994). Second, if the probability of mortality is lower for larger individuals, then larvae with faster growth may gain an advantage with respect to avoiding predation, obtaining food, and the ability to withstand starvation (Miller et al. 1988, Bailey and Houde 1989, China and Holzman 2014). Selective mortality of smaller and slower-growing larvae has been observed in a variety of fish species (Hoey and McCormick 2004, Rankin and Sponaugle 2011, D'Alessandro et al. 2013); however other studies have also shown that larger, faster-growing fish may have higher mortality (Litvak and Leggett 1992, Pepin et al. 1992, Bertram and Leggett 1994, Leggett and DeBlois 1994). Finally, larvae with a shorter larval duration may avoid high mortality in this stage associated with predation (Rankin and Sponaugle 2014) and have a higher chance of survival to become a juvenile (Anderson 1988, Cushing 1990). Therefore, extension of the larval period (delayed settlement) caused by slower developmental rates or through physical processes such as currents, storms, and upwelling events that prevent larvae from reaching suitable settlement habitat may increase mortality (Houde 1987, Cowen 2002, Leis and McCormick 2002, Schmitt and Holbrook 2002).

One of the principal factors influencing individual trait variability is food availability (Takahashi and Watanabe 2005, Voss et al. 2006). Food availability is particularly 
important to larval survival because larvae have high metabolic rates and low energy reserves (Fuiman 2002). After only a few days without food, the larvae of some fish species are unable to survive, at which time they reach a "point of no return" (Eldredge et al. 1981, McGurk 1984, Rana 1985). Larval fishes have a varied diet consuming small zooplankton in early stages and often transitioning to larger zooplankton such as copepods as they get bigger (Miller and Allen 2006, Voss et al. 2006). Phytoplankton, as represented by chlorophyll a (Chl-a) concentration, are consumed by zooplankton and are often used as a proxy for food availability (Caselle et al. 2012b, Woodson et al. 2012a). Significant positive relationships between $\mathrm{Chl}$-a concentration and abundance of copepods have been reported in a diverse range of environments such as offshore temperate (Durbin et al. 1983; Kiørboe and Nielsen 1994) and tropical waters (Hopcroft and Roff 1998; Hopcroft et al. 1998), and in shallow estuaries (Landry 1978; Ambler 1986; Beckman and Peterson 1986).

One factor related to decreased phytoplankton production (i. e. food availability) is increased sea surface temperature (SST), which may indicate periods with low upwelling and potential stratification of the water column (Behrenfeld et al. 2006, Leising et al. 2015). Upwelling occurs along the west coast of the United States primarily in spring and summer when strong winds from the north and northwest move surface waters offshore, which are then replaced with cooler, nutrient-rich water from depth. During upwelling events, increased phytoplankton growth supports a trophic pyramid that includes zooplankton and many fish species (Ryther 1969). When upwelling ceases, SST rises, stratification increases and there is decreased productivity (Behrenfeld et al. 2006). In addition to potentially decreasing food availability, warmer water temperatures may increase metabolic rate and energetic demand of consumers making 
low phytoplankton availability even more problematic (Clarke and Fraser 2004, Comerford et al. 2013). During a long-term shift to a warm water regime as the result of changing Pacific Decadal Oscillation, Moser et al. (2000) observed an overall reduction in phyto- and zooplankton of $46 \%$ and an average decline in larval rockfish of $52 \%$ from the cool to the warm regime.

Ocean currents can also change concentration or supply of food sources (Zimmerman and Kremer 1984, Witman et al. 1993, Druce and Kingsford 1995, Woodson et al. 2012b). For example, a study examining how current regimes in the California Current Ecosystem (CCE) affect recruitment in multiple species of intertidal invertebrates (Balanus spp., Chthamalus spp., Mytilus spp.) and rockfishes (Sebastes spp.) found that the presence of ocean fronts associated with periods of coastal upwelling were positively correlated with increased chlorophyll and recruitment (Woodson et al. 2012b). In fact, currents may affect settlement in a variety of ways, including: 1) retention of larvae due to features such as eddies increasing settlement (Milicich 1994; Vargas et al. 1998; Logerwell and Smith 2001), and 2) larval drift with prevailing currents displacing larvae and decreasing local settlement (Hutchins and Pearce 1994; Milicich 1994).

Lunar phase is another factor associated with settlement patterns of marine organisms (Kingsford and Finn 1997, Reyns and Sponaugle 1999). For example, settlement near the new moon has been found for many fish species that utilize estuaries as juvenile nurseries such as flounder (Paralichthys, Williams and Deubler 1968), Atlantic croaker (Micropogonias undulates, Hettler and Chester 1990), and Yellowfin bream (Acanthopagrus australis, Pollock et al. 1983). Moving into the estuary during the new moon when current velocities are higher may be a strategy to maximize ingress towards 
nursery habitats (Anderson et al. 2007). In coral reef fishes, stronger settlement near the new moon has been observed for blue chromis (Chromis cyanea, Anderson et al. 2007) and bicolor damselfish (Stegastes partitus, Robertson et al. 1987) and has been hypothesized as a strategy to utilize the darker night to minimize predation by visual nocturnal feeders. However if larval duration is fixed, peak larval input may also reflect the timing of spawning (Pollock et al. 1983, Rhodes 2012).

Understanding how settlement is affected by environmental conditions such as water temperature is especially important to gain insight into how warming ocean conditions may impact marine populations. The global ocean SST in 2014 was the hottest on record, at $0.57^{\circ} \mathrm{C}$ above the $20^{\text {th }}$ century average, which was surprising considering the neutral El Niño conditions observed for most of that year (Blunden and Arndt 2015). In the northeast Pacific Ocean, during the winter of 2013-14, weakened winds and unusually high sea level pressure formed a region where heat was retained in surface water. This mass of warm water, known as "the blob" reached coastal waters in the western United States in spring/summer of 2014 (Bond et al. 2015). A geographically distinct section of the blob near San Diego was named the Southern California Warm Anomaly (SCWA, Leising et al. 2015), and was partially responsible for the shift in the California Current from a productive La Niña state in 2013 to a warm area with low productivity (Leising et al. 2014).

Our objective was to examine how changes in environmental conditions over four years may affect daily and annual settlement success of spotted sand bass (Paralabrax maculatofasciatus) in Mission Bay, CA. We also examined how environmental conditions influenced individual characteristics at settlement (length, age, condition, larval growth rates). The sampling years (2012-2015) included two years of relatively normal 
conditions (2012-13) followed by the arrival of the SCWA in 2014 and dramatic changes in Chl-a and SST that continued through 2015. 


\section{MATERIALS AND METHODS}

\section{Study species}

Spotted sand bass (Paralabrax maculatofasciatus) are a recreationally important fish in Southern California typically found from Santa Monica Bay, CA in the north to Mazatlan, Mexico in the south (Allen et al. 1995). There are two main populations of $P$.

maculatofasciatus along this range: one in the Gulf of California and another in the Pacific along Baja California and Southern California (Tranah and Allen 1999). Spotted sand bass are primarily found in calm, shallow, nearshore habitats such as bays and estuaries (Allen et al. 1995). Unlike other common southern California serranids (kelp bass, $P$. clathratus, and barred sand bass, P. nebulifer), P. maculatofasciatus typically remain within coastal bays and do not migrate along the open coast as adults (Allen et al. 1995). Adults spawn near the entrance of bays in the summer (Allen et al. 1995), are capable of spawning multiple times throughout the season (Quast 1968) and may even spawn daily (Oda et al. 1993). A laboratory study by Miller and Allen (2006) found that egg production was significantly correlated with mean water temperature for each month, with the highest egg production occurring during July when the water was warmest. After spawning, the pelagic eggs enter the plankton in coastal waters and hatch into larvae (Allen et al. 1995). Pelagic larval duration (PLD) for spotted sand bass is approximately one lunar month ( $28 \mathrm{~d}$ ) with size at settlement near $10 \mathrm{~mm}$ standard length (Allen and Block 2012). Larvae settle to bays and estuaries that contain structured habitats such as eelgrass, surfgrass, and rock relief (Fitch and Lavenberg 1975). There is likely a high degree of larval retention as $P$. maculatofasciatus sampled 
near San Diego are genetically distinct from those found further down the Baja California peninsula (Tranah and Allen 1999).

\section{Larval fish collection and morphometric analysis}

Recently settled P. maculatofasciatus were collected weekly from June - October in 2012, 2013, 2014 and 2015 near the Mission Bay inlet, San Diego, CA (Fig. 1). Fish were collected using a modification of the Standard Monitoring Units for the Recruitment of Fishes (SMURFs) design (Ammann 2004). Each collector (0.5 x $0.18 \mathrm{~m}$ dia.) consisted of a narrow cylinder of plastic fencing material with a $2.5 \mathrm{~cm}$ grid filled with giant kelp (Macrocystis pyrifera). The kelp attracts juvenile fish that use this habitat as a shelter, and the fencing material prevents access by larger predators (Connell 1997). Three replicate collectors were positioned $5 \mathrm{~m}$ apart in approximately $4 \mathrm{~m}$ of water and attached to a cinder block anchor with a brass clip and floated upright with a Styrofoam float (Fig. 2). Collectors were placed near the bottom to ensure they would not be disturbed by boat traffic, and were the only structure along the sandy bottom of the surrounding area thereby maximizing the chance that late stage larvae arriving to this area would shelter in them. Collectors were retrieved weekly by snorkeling to depth, enclosing the collector in a $1 \mathrm{~mm}$ mesh bag, unclipping it and bringing it back to shore where all fishes were removed and preserved in $70 \%$ ethanol for later identification. Following collection, the kelp was investigated and if it had started to deteriorate, the old kelp inside the collector was replaced and the collector was returned to its mooring.

In the laboratory, standard length of each fish was measured from individual digital images using Image-J analysis software (Hinaux et al. 2011). Images were obtained by placing each fish on a calibrated slide and using an Amscope MU1000 digital video 
camera attached to an Olympus SDF PLAPO 0.5XPF dissecting microscope. Next, for age determination (see below), the sagittal otoliths were removed. Following otolith extraction, fish dry weight was obtained by placing fish into a drying oven at $60^{\circ} \mathrm{C}$ for 24 h, allowing them to cool for 5 min and weighing them on a sealed OHAUS Discovery DV215CD balance to the nearest $0.1 \mathrm{mg}$. Finally, body condition at settlement, a measure of fatness, was estimated with the equation: condition = dry weight $\mathrm{x}$ standard length ${ }^{-3}$ (Wootton 1990).

\section{Otolith analysis}

Sagittal otoliths were mounted to microscope slides using thermoplastic glue (Crystal Bond). One sagitta was randomly chosen and polished to the core using 200-600 grit sandpaper. All abnormally shaped and unclear (large portions with no discernable increments) otoliths were discarded ( $n=9$ from a total of 102). Images of sagitta were taken using an Olympus BH2-RFCA transmitted light microscope at 250x equipped with a Moticam Pro 282B digital camera. All otoliths were measured using Image-Pro image analysis system (Allen and Block 2012). Otoliths were measured along their longest radius from the core to the outer edge and distance from the core to each increment was measured and counted. Because daily ring deposition in P. maculatofasciatus is thought to begin at the third day post hatch, two days were added to each ring count in all age estimates to account for the delay in ring formation before yolk absorption (Allen and Block 2012). Each sagitta was read blind, and after completing all sagitta once they were read blind again. If counts differed by $\geq 3$ increments $(\sim 10 \%)$ between the two readings, the otolith was reread. If the third count was within 1 count of the former readings, then one of the readings was randomly chosen for analysis. Alternatively, if 
the difference was $>2$ of the previous readings, the otolith was discarded (Searcy et al. 2007).

Fish collectors were only retrieved once a week, therefore records of daily settlement required us to back calculate settlement dates. Fortunately, P. maculatofasciatus have a 'settlement check' on their otoliths, identified as an abrupt change in the width of daily bands at the time of settlement (Fig. 3, Allen 2012). This check may be the result of altered growth or metabolic rate during a period of increased stress such as the transition from a pelagic to a demersal life style (Gauldie 1991). If no check was apparent, the fish was considered to be collected during its initial process of settlement. From these measurements, larval duration and average pre-settlement otolith growth were determined. Finally, to estimate standard length at settlement for all fish collected, we first calculated the linear regression among all years for standard length at collection to age at collection (Fig. 4), and then used the equation of the line to back calculate standard length at settlement (e. g., Allen and Block 2012).

\section{Environmental data}

Because we were interested in environmental conditions such as sea surface temperature (SST) and chlorophyll a (Chl-a) during the period in which $P$. maculatofasciatus develop offshore, all annual means of environmental variables were calculated by averaging conditions from May - October to incorporate the period from first potential spawning (approximately 1 month prior to our first sample) until the final retrieval of collectors. Environmental conditions were estimated for an offshore region that encompassed the potential area (Fig. 5) that larvae arriving to San Diego might be spawned from (Tranah and Allen 1999), historical offshore distribution (Moser et al. 
2001), as well as potential transport of larvae given a larval duration of 28 days (Allen and Block 2012) and current speed of $0.2 \mathrm{~m} / \mathrm{sec}$ (Apr-Jul, Oct-Jan 2014 average; Reyns, Pineda, Lentz unpublished data). Values for daily SST and Chl-a were obtained from satellite data from the Environmental Research Division of Southwest Fisheries Science Center. Chl-a concentration and SST were collected in RStudio using the R package Xtractomatic (Mendelssohn 2015), which uses satellite measurements at a grid interval of $5.5 \mathrm{~km}$ for SST (dtype 15) and $2.5 \mathrm{~km}$ for Chl-a (dtype 21). These data were used to determine both intra- and interannual changes in Chl-a and SST, which were directly compared to daily settlement. For interannual comparisons, Chl-a and SST were averaged over a mean 25 day larval duration for each individual fish, which was then averaged for all fish for the entire year. To determine whether Chl-a in the surface waters in weeks prior to settlement may affect larvae, a series of Chl-a lags (1-wk, 2-wk, 3-wk) were created using daily Chl-a values 1, 2, or 3 weeks prior to a given day of settlement.

Wave height and direction data were collected from the National Data Buoy Center station 46231 (Fig. 1), which calculated the average of the highest one-third of all wave heights and average direction from which waves are coming in degrees (i. e. $0^{\circ}$ being North) during each 20-minute sampling period. Wind direction and both mean and maximum wind speed data were obtained from San Diego International Airport (Fig. 1), provided by the Automated Surface Observation System from Weather Underground (Cogliani 2001). These measurements were based on 24 separate hourly measurements made throughout each day. Upwelling index and alongshore Ekman transport values were accessed from the NOAA Pacific Fisheries Environmental Laboratory database, station 93950-2097, which collects measurements of atmospheric pressure at mean sea 
level every six hours (Fig. 5). A qualitative assessment of large scale current patterns was also completed using High Frequency Radar data provided by the Southern California Coastal Ocean Observing System (SCCOOS). Radar maps of daily mean currents were examined for changes in current regimes or the presence of gyres. We also examined the qualitative relationship between lunar cycle and proportion of settlement during each lunar day (Fig. 6). Annual proportion of settlement was averaged for each lunar day from monthly proportion of settlement.

\section{Data analysis}

To determine whether there were significant differences in annual settlement, environmental conditions (Table 1), and larval traits (age-, length-, condition-atsettlement, Table 2) we first examined these factors for normality and homogeneity of variance. To test for significance among years, an ANOVA or the nonparametric equivalent (Kruskal-Wallis) was used. When significant differences in these factors occurred among years, t-tests or the nonparametric equivalent (Wilcoxon rank sum test) were performed. Small sample sizes in 2014 and 2015 made it difficult to determine statistical differences in larval traits among years. To estimate the minimum sample size required, post-hoc power analysis was run (alpha $=0.05)$.

Finally, to analyze daily increment growth in otoliths among years, a repeated measures multivariate analysis of variance (MANOVA) was run (Robert el al. 2007). The MANOVA allows for comparisons among individual fish (Chambers and Miller 1995, Meekan and Fortier 1996). Comparisons were made among groups with the null hypothesis of no difference. Four test statistics were used, each of which was based on sample size, 
number of groups in the comparison, and number of intervals being analyzed (e. g. Searcy and Sponaugle 2000).

To determine the importance of SST, Chl-a, wind, upwelling, and Ekman transport on settlement, we tested the plausibility of 45 a priori candidate models that included various combinations of environmental parameters (Table 3). In order to keep the total number of models manageable, we first removed environmental variables that did not appear to affect settlement when considered alone (Zabel et al. 2011). We included quadratic terms for SST and Chl-a because we hypothesized that optimal settlement may occur at intermediate values. Because the settlement data was not normally distributed, we explored the fit of alternative distributions with generalized linear models (negative binomial, Poisson, zero-inflated) and determined that a negative binomial distribution best fit the data. During testing, it was also noted that residuals from the settlement models were temporally autocorrelated, violating the assumption that each settlement sample was independent (Bullmore et al. 1996). Thus, we utilized generalized linear models that accounted for serial temporal autocorrelation to analyze the data as implemented by the R package tscount (Liboschik et al. 2016). Relative model plausibility was evaluated based on Akaike's Information Criterion controlled for small sample size (AICC) scores (e. g., Burnham and Anderson 2002). To determine which independent variables had a significant effect on larval settlement, and the strength of those effects, model-averaged slopes and $95 \%$ confidence intervals were calculated for each independent variable (Table 4). Variability was considered to have a significant impact if the confidence intervals did not overlap zero. 


\section{RESULTS}

\section{Abundance and individual characteristics}

The total number of spotted sand bass (Paralabrax maculatofasciatus) collected had a distinct temporal trend with significantly more fish collected in 2012-2013 than 20142015 (Fig. 7). Individual characteristics also varied annually with mean standard length (SL) at settlement significantly lower in 2012, with a trend toward longer fish in 2014-15 (ANOVA: $F=15.93, d f=1, p=0.00013 ; F i g .8 a$ ). $S L$ at collection was significantly lower in 2012-2013 than in 2014-2015 (ANOVA: $F=9.09, d f=3, p<0.05 ;$ Fig. 8b). Body condition, a measure of body fatness, was significantly greater in 2012 and showed a trend of fish with higher condition in 2012-2013 than 2014-2015 (Fig. 9). Otolith derived traits also had mixed trends. In 2012, fish were significantly younger at settlement, and there was a trend of younger fish in 2013 as well (Fig. 10). Due to the high degree of error associated with the small sample size in $2015(n=5)$, mean pelagic larval duration in that year overlapped with both 2013 and 2014. This high degree of error in 2015 was also observed in annual and daily mean otolith growth, where fish in 2014 had significantly lower rates of growth than other years (Fig. 11, Table 5). Small sample sizes in 2014 and 2015 made it difficult to determine statistical differences in larval traits among years. Post-hoc power analysis suggests that the sample size of $2015(n=5)$, assuming a moderate effect size (0.25) and a standard alpha (0.05), would result in relatively low power (0.12). With these same parameters, using the sample size of 2014 $(n=12)$ results in increased power $(0.25)$, however it remains low. To obtain higher power (e. g. 0.6), sample size would need to be approximately $n=30$ for all groups. 


\section{Environmental Conditions}

To determine whether annual settlement success of $P$. maculatofasciatus was related to environmental conditions, we examined chlorophyll a (Chl-a) concentration, sea surface temperature (SST), maximum wind speed, average wind speed, upwelling index, and alongshore Ekman transport. Wave height, wave direction, and wind direction were not considered in this analysis, as these factors were not significantly different among years and none were significantly related to settlement in our initial correlation analyses. Lunar phase was also excluded from further analyses, as it did not show a clear trend with daily settlement (Fig. 6, Table 6). Annual mean SST was significantly lower in 2012 and 2013 (17.95 and $17.77{ }^{\circ} \mathrm{C}$ respectively, Fig. 12), relative to 2014 (19.41 ${ }^{\circ} \mathrm{C}$, Fig. 12) and 2015 (19.83 ${ }^{\circ} \mathrm{C}$, Fig. 12). Wind speed was significantly higher in 2012-13 compared to 2014-15 (Fig. 13). Additionally, mean wind speed had a significant effect on settlement in both 2014 and 2015 (Table 7). Upwelling index was significantly higher in 2012-13 compared to 2014-15 (Fig. 14). Alongshore Ekman transport was significantly lower in 2014 compared to the other years (Fig. 15). We did not observe any differences in current speed or direction among the four years of our study (Table 1).

To examine the combined effect of these environmental conditions, a model selection analysis using Akaike's Information Criterion controlled for small sample size (AICC) scores found that a combination of Chl-a, SST, and average wind speed had the most significant impact on settlement (Table 3 ). However, the model selection analysis showed that all included factors, in various combinations, also impacted settlement (Table 3). Individually, Chl-a and average wind speed also had significant impacts on settlement, as their 95\% confidence intervals did not overlap with zero, with Chl-a having the strongest effect by far (Table 4). Annual mean sea surface Chl-a varied 
significantly among years and was highest in 2012 and 2013 (1.14 and $1.04 \mu \mathrm{g} \mathrm{L}$

respectively, Fig. 16), reduced by nearly half in 2014 (0.59 $\mathrm{\mu g} \mathrm{L}^{-1}$, Fig. 16), and was even lower in 2015 (0.44 $\mu \mathrm{g} \mathrm{L}^{-1}$, Fig. 16).

When examining intra-annual variation in settlement, we observed an apparent lagged relationship with Chl-a (Fig. 17). Peaks in settlement follow relative maxima in Chl-a after a lag of approximately 15 - 20 days. For example, in 2013 the first major Chl-a bloom on June $7^{\text {th }}$ is followed 20 days later by the beginning of a settlement increase on June $27^{\text {th }}$. A second Chl-a peak on July $23^{\text {rd }}$ is followed by another peak in settlement 16 days later on August $8^{\text {th }}$ (Fig. 17b). In a series of multiple regressions combining each of the environmental conditions listed above, as well as analyses including multiple week lags for Chl-a, a significant relationship was found between settlement in 2013 and Chl-a concentration two weeks prior $(p=0.028$, Table 7). 


\section{DISCUSSION}

Settlement of spotted sand bass (Paralabrax maculatofasciatus) to Mission Bay varied both intra- and interannually. This result is not surprising as previous studies involving both fishes (Bergenius et al. 2002, Wilson et al. 2008) and invertebrates (Navarrete et al. 2002, Wing et al. 2003) have shown settlement to be temporally variable. Variable settlement patterns have been related to factors including lunar phase (Kingsford and Finn 1997, Reyns and Sponaugle 1999), current regimes (Schirripa and Colbert 2006, Wei et al. 2009), sea surface temperature (SST, Wing et al. 2003, Laidig et al. 2007), and availability of planktonic prey (Birkeland 1982, Rankin and Sponaugle 2014). In this study, we saw higher settlement of P. maculatofasciatus in 2012-13 and lower settlement in 2014-15. We attribute the overall reduction in number of larval fish arriving to Mission Bay in 2014 and 2015 to the arrival of the Southern California Warm Anomaly (SCWA, Leising et al. 2015).

The SCWA, which formed in the NE Pacific, moved to coastal southern California in May of 2014, bringing unusually warm surface water (< $100 \mathrm{~m}$ depth, Bond et al. 2015, Goericke and CalCOFI Tech. Group 2015) and low chlorophyll a (Chl-a) levels (Whitney 2015). Although fish in 2014-15 showed a trend toward longer back calculated standard length at settlement (Fig. 8), fish in these years also tended to be older at settlement (Fig. 10), have lower otolith growth rates (Fig. 11) and have a lower body condition (Fig. 9), indicating that larvae in 2014-15 were less successful feeders. The larval traits of fish in 2014-15 may also be related to increased metabolic stress as the result of higher SST (Comerford et al. 2013). As a caveat, it should be noted that fish collected in 2015 had significantly higher otolith growth rates than other years (Fig. 11), however, this may be 
the result of small sample size that year skewing the data $(n=5)$. Power analysis suggests that a minimum of 30 fish would be required to find a significant difference in larval traits.

Our finding that warmer water temperatures and otolith growth are negatively related contradicts the common observation that increased water temperature is related to faster growth in larvae (Houde 1989, Morse 1989, Comerford et al. 2013). This discrepancy may be due to the combined impacts of lower food availability in 2014-15, in addition to warmer water temperatures that increase metabolism and amount of food required to survive (Houde 1989, Morse 1989, Comerford et al. 2013). Low offshore Chl-a levels, like those observed during the SCWA, are thought to indicate a poor feeding environment for larval fishes which consume small zooplankton such as copepods (Caselle et al. 2010b). Indeed, areas with high Chl-a have been related to enhanced recruitment of larvae that consume phytoplankton directly (e. g. barnacle) and indirectly (e. g. rockfish) across the entire California Current Ecosystem (CCE, Woodson et al. 2012b).

The reduction in Chl-a values found in our study may be attributed to warmer sea surface temperatures that increase stratification and reduce the flux of nutrients into sunlight surface waters (Leising et al. 2015). While wind speed was statistically related to settlement, it is more likely that the weaker winds in 2014 and 2015 indirectly impacted settlement by allowing stratification of the water column, as evidenced by decreased values of upwelling index observed in these years. Phytoplankton in the surface layers of the ocean rely on upwelling of nutrients for continued growth, and increased stratification is often followed by decreased productivity (Behrenfeld et al. 2006). During the SCWA, compared to the previous 30 years, stratification was the 
strongest, surface nutrient levels of nitrate were approximately $0.02 \mu \mathrm{M}$ lower, and Chla values were the lowest observed over the entire time period (Leising et al. 2015).

Similar patterns have been observed in previous work which suggests there is an inverse relationship between SST and productivity in the CCE (McGowan et al. 2003, Palacios et al. 2004) as well as more generally in the oceans (Behrenfeld et al. 2006). Wind direction was consistent throughout our study period, and showed no significant variation from a westerly onshore flow among years. Alongshore Ekman transport was significantly lower in 2014 , however the difference among years, and relationship with settlement, was not clear.

The increased PLD in 2014-15, supported by the fact that fish in these years had longer SL at settlement, may be the result of changing current patterns with the introduction of the SCWA, which could prevent larvae from reaching the coast and delay settlement. A recent study in the CCE examined how movement of the warm anomaly to coastal waters in 2014 changed current patterns and altered settlement in 30 species of nudibranchs (Goddard et al. 2016). Northward ranges of typically southern nudibranch species may have been facilitated by increased poleward and onshore transport of their planktonic larvae (Goddard et al. 2016). This stronger poleward current is expected during periods of reduced upwelling, which was observed in 2014 off northern Baja California and southern California (Leising et al. 2014). We expect a poleward shift in the CCE would not affect settlement of $P$. maculatofasciatus in Mission Bay, because it is located near the northern end of their range. Any poleward movement alongshore would likely bring larvae to the bay from populations further south.

Our results, showing a negative relationship between SST and settlement, provide an interesting contrast to a previous study that examined quarterly juvenile abundance of 
over 100 species of fish to the artificial breakwaters at King Harbor, CA over an 18 year period (Stephens et al. 1994). King Harbor, CA is approximately $160 \mathrm{~km}$ northwest of our study location. In this study both $P$. maculatofasciatus and the barred sand bass ( $P$. nebulifer) had increased juvenile abundance during times of higher SST such as the EI Nino events of 1977-78 and 1982-83 (Stephens et al. 1994). The authors also note these periods had decreased Chl-a and likely lower food availability. The opposite trends between our study and the previous work may be due to the abnormally high SST of our study site in $2014-15$, which was approximately $2{ }^{\circ} \mathrm{C}$ higher than the annual mean SST in the King Harbor study. Furthermore, the King Harbor study focused on juveniles found in the harbor post-settlement, which may have allowed juvenile fish time to aggregate to the breakwater, as opposed to our study which examined initial settlement of larvae. Another possible explanation for the decreased settlement in our study involves increased SST affecting reproduction. Although reproduction and recruitment rates are positively associated with SST in Pacific sardine (Jacobson and MacCall 1995), increased SST has negatively affected egg quality and hatch success in Atlantic salmon (King et al. 2003) and anemonefish (Miller et al. 2015), and negatively affected spawn success and egg production in demersal species in Southern California such as the blackeyed goby (Coryphopterus nicholsi) and garibaldi (Hypsypops rubicundus, Stephens et al. 1994). H. rubicundus actually left their shallow nests within a harbor due to increased water temperature. Although it is possible that $P$. maculatofasciatus, which spawns within the shallows of bays and estuaries, may also abandon their spawning grounds for deeper areas as water temperatures rise, spotted sand bass are typically considered a warm water species. In San Diego, spotted sand bass are at the northern end of their range which extends into much warmer waters throughout the Gulf of California (Allen et al. 
1995). Furthermore, P. maculatofasciatus typically produces more eggs throughout the summer as water temperature increases, with the highest egg production occurring during July when the water is warmest (Allen et al. 1995, Miller and Allen 2006). Also, unlike other members of Paralabrax common in southern California (kelp bass and barred sand bass), spotted sand bass adults typically remain in shallow coastal embayments their entire lives and may be especially resistant to higher water temperatures (Allen et al. 1995).

The idea that Chl-a and settlement of spotted sand bass are related is supported by closer examination of intra-annual trends in settlement during 2013 as it had the highest settlement of our four year study. Similar to the annual trends, we found a relationship between settlement and Chl-a: peaks in $P$. maculatofasciatus settlement followed approximately 2-3 weeks after peaks in Chl-a (Fig. 17b, Table 7). The importance of Chl-a to settlement this year is further stressed by the lack of elevated SST (Fig. 18b). In fact, there did not appear to be any clear relationship between SST and settlement in 2013 (Fig. 18b, Table 7). Lunar phase is another factor known to affect settlement during different times of the spawning season, in species such as convict surgeonfish (Randall 1961), French grunt (McFarland et al. 1985), and bicolor damselfish (Rankin and Sponaugle 2014). In our study, there was no clear relationship between phase of the moon and settlement of $P$. maculatofasciatus. On the intra-annual scale, as with interannual, it appears chlorophyll is highly related to settlement.

In 2014-15, we propose that increased SST associated with the SCWA combined with decreased food availability due to nutrient stratification formed an environment that limited survival of larval P. maculatofasciatus. Many predictions for the future climate of our oceans indicate that SST will increase (e. g. Nixon et al. 2004, Hoegh-Guldberg et al. 
2007, Seekall and Pace 2011, Howell and Auster 2012). This study gives us insight into how increasing water temperatures may affect settlement and recruitment patterns of fishes in southern California. 


\section{LITERATURE CITED}

Alford RA and Harris RN (1988) Effects of larval growth history on anuran metamorphosis. American Naturalist 131:91-106

Allen LG, Hovey TE, Love MS, Smith JTW (1995) The life history of the spotted sand bass (Paralabrax maculatofasciatus) within the Southern California Bight. CalCOFI Rep 36:193-203

Allen LG, Block HE (2012) Planktonic larval duration, settlement, and growth rates of the young-of-the-year of two sand basses (Paralabrax nebulifer and P. maculatofasciatus: fam. Serranidae) from Southern California. Bulletin, Southern California Academy of Sciences 111:15-21

Ambler JW (1986) Effect of food quantity and quality on egg production of Acartia tonsa Dana from East Lagoon, Galveston, Texas. Estuarine Coastal and Shelf Science 23:183196

Ammann AJ (2004) SMURFs: Standard monitoring units for the recruitment of temperate reef fishes. Journal of Experimental Marine Biology and Ecology 299:135-154

Anderson JT (1988) A review of size dependent survival during pre-recruit stages of fishes in relation to recruitment. Journal of Northwest Atlantic Fishery Science 8:55-66

Anderson TW, Carr MH, Hixon MA (2007) Patterns and mechanisms of variable settlement and recruitment of a coral reef damselfish, Chromis cyanea. Marine Ecology Progress Series 350:109-116

Bailey KM, Houde ED (1989) Predation on eggs and larvae of marine fishes and the recruitment problem. Advances in Marine Biology 25:1-83

Beckman BR and WT Peterson (1986) Egg production by Acartia tonsa in Long Island Sound. Journal of Plankton Research 8:917- 925

Behrenfeld MJ, O'Malley RT, Siegel DA, McClain CR, Sarmiento JL, Feldman GC, Milligan AJ, Falkowski PG, Letelier RM, Boss ES (2006) Climate-driven trends in contemporary ocean productivity. Nature 444:752-755

Bergenius MAJ, Meekan MG, Robertson DR, Mccormick MI (2002) Larval growth predicts the recruitment success of a coral reef fish. Oecologia 131:521-525

Bertness MD and Gaines SD (1993) Larval dispersal and local adaptation in acorn barnacles. Evolution 47:316-320

Bertram DF and Leggett WC (1994) Predation risk during the early life history periods of fishes: separating the effects of size and age. Marine Ecology Progress Series 109:105114 
Birkeland C (1982) Terrestrial runoff as a cause of outbreaks of Acanthaster planci (Echinodermata: Asteroidea). Marine Biology 69:175-185

Blunden J and Arndt DS (2015) State of the climate in 2014. Bulletin of the American Meteorological Society 96:S1-S238

Bond NA, Cronin MF, Freeland H, Mantua N (2015) Causes and impacts of the 2014 warm anomaly in the NE Pacific. Geophysical Research Letters 42:3414-3420

Bullmore E, Brammer M, Williams SC, Rabe-Hesketh S, Janot N, David A, Mellers J, Howard R, Sham P (1996) Statistical methods of estimation and inference for functional MR image analysis. Magnetic Resonance in Medicine 35:261-277

Burnham KP and Anderson DR (2002) Model selection and multimodel inference: a practical information-theoretic approach (2nd ed). Springer, USA.

Caselle JE, Kinlan BP, and Warner RR (2010a) Temporal and spatial scales of influence on nearshore fish settlement in the southern California Bight. Bulletin of Marine Science 86:355-385

Caselle JE, Carr MH, Wilson JR, and Wendt DE (2010b) Can we predict interannual and regional variation in delivery of pelagic juveniles to nearshore populations of rockfishes (genus Sebastes) using simple proxies of ocean conditions? California Cooperative Oceanic Fisheries Investigations 51:91-105

Chambers RC, Miller TJ (1995) Evaluating fish growth by means of otolith increment analysis: special properties of individual-level longitudinal data. In: Secor DH, Dean JM, Campana SE (eds) Recent developments in fish otolith research. University of South Carolina Press, Columbia, p. 155-175

China V and Holzman H (2014) Hydrodynamic starvation in first-feeding larval fishes. Proceedings of the National Academy of Sciences 111:8083-8088

Clarke A, Fraser KPP (2004) Why does metabolism scale with temperature? Functional Ecology 18:243-251

Cogliani E (2001) Air pollution forecast in cities by an air pollution index highly correlated with meteorological variables. Atmospheric Environment 35:2871-2877

Comerford SD, Brophy CJ, Fox N, Taylor HW, van der Veer RDM, Nash and Geffen AJ (2013) Temperature effect on growth and larval duration of plaice Pleuronectes platessa in three regions of the Northeast Atlantic. Marine Ecology Progress Series 476:215-226

Connell SD (1997) The relationship between large predatory fish and recruitment and mortality of juvenile coral reef-fish on artificial reefs. Journal of Experimental Marine Biology and Ecology 209:261-278 
Cowen RK (2002) Larval dispersal and retention and consequences for population connectivity. Coral reef fishes: dynamics and diversity in a complex ecosystem.

Academic Press, San Diego, CA, p. 149-170

Cushing DH (1990) Plankton production and year-class strength in fish populations: an update of the match/mismatch hypothesis. Advances in Marine Biology 26:142-155

D'Alessandro EK, Sponaugle S, and Cowen RK (2013) Selective mortality during the larval and juvenile stages of snappers (Lutjanidae) and great barracuda Sphyraena barracuda. Marine Ecology Progress Series 474:227-242

Druce BE and Kingsford MJ (1995) An experimental investigation on the fishes associated with drifting objects in coastal waters of temperate Australia. Bulletin of Marine Science 57:378-392

Durbin EG, Durbin AG, Smayda TJ, and Verity PG (1983) Food limitation of production by adult Acartia tonsa in Narragansett Bay, Rhode Island. Limnology and Oceanography 28:1199-1213

Eldredge MB, Whipple JA, Eng D, Bowers MJ, and Jarvis BM (1981) Effects of food and feeding factors on laboratory-reared striped bass larvae. Transactions of the American Fisheries Society 110:111-120

Fitch JE and Lavenberg RJ (1975) Tidepool and nearshore fishes of California. University of California Press, p. 156

Fuiman LA and Magurran AE (1994) Development of predator defenses in fishes. Reviews in Fish Biology and Fisheries 4:145-183

Fuiman LA (2002) Special considerations of fish eggs and larvae. Fishery science: the unique contributions of early life stages. Blackwell Science, Oxford, UK, p. 1-32

Fuiman LA and Werner RG (2002) Fishery science: the unique contributions of early life stages. Blackwell Science, Oxford, UK, p. 326

Gauldie RW (1991) The morphology and periodic structures of the otolith of the Chinook salmon (Oncorhynchus tshawytscha), and temperature-dependent variation in otolith microscopic growth increment width. Acta Zoologica 72:159-179

Goddard JHR, Barbara S, Treneman N, Pence WE, Mason DE, Ramon S, Dobry PM, Bay E, Green B, Francisco S, Hoover C (2016) Nudibranch range shifts associated with the 2014 warm anomaly in the NE Pacific. Bulletin of the Southern California Academy of Sciences 115:15-40

Goericke R and CalCOFI Tech. Group (2015) The 2014/15 warm anomaly in the southern California current. CaICOFI Report. 
Hinaux H, Pottin K, Chalhoub H, Père S, Elipot Y, Legendre L, Rétaux S (2011) A developmental staging table for Astyanax mexicanus surface fish and pachon cavefish. Zebrafish 8:155-165

Hixon MA, Webster MS (2002) Density dependence in marine fishes: coral reef populations as model systems. Coral Reef Fish p. 303-325

Hoegh-Guldberg O, Harvell CD, Sale PF, Edwards AJ, Caldeira K, Knowlton N, Eakin CM (2007) Coral reefs under rapid climate change and ocean acidification. Science 318:1737-1742

Hoey AS, McCormick MI (2004) Selective predation for low body condition at the larvaljuvenile transition of a coral reef fish. Oecologia 139:23-29

Hopcroft RR and Roff JC (1998) Zooplankton growth rates: The influence of female size and resources on egg production of tropical marine copepods. Marine Biology 132:7986

Hopcroft RR, Roff JC, Webber MK, and Witt JDS (1998) Zooplankton growth rates: The influence of size and resources in tropical marine copepodites. Marine Biology 132:6777

Houde ED (1987) Fish early life dynamics and recruitment variability. American Fisheries Society Symposium 2:17-29

Houde ED (1989) Subtleties and episodes in the early life of fishes. Journal of Fish Biology, 35(Supplement A):29-38

Houde ED (1996) Evaluating stage-specific survival during the early life of fish. Survival strategies in early life stages of marine resources. A. A. Balkema, Rotterdam, The Netherlands, p. 51-66

Houde ED (2002) Mortality. Fishery science: the unique contributions of early life stages. Blackwell Science, Oxford, UK, p. 64-87

Houde ED (2008) Emerging from Hjort's shadow. Journal of Northwest Atlantic Fishery Science 41:53-70

Howell P and Auster PJ (2012) Phase shift in an estuarine finfish community associated with warming temperatures. Marine and Coastal Fisheries: Dynamics, Management, and Ecosystem Science 4:481-495

Hutchins JB and Pearce AF (1994) Influence of the Leeuwin Current on recruitment of tropical reef fishes at Rottnest Island, Western Australia. Bulletin of Marine Science 54:245-255

Jacobson LD, MacCall AD (1995) Stock-recruitment models for Pacific sardine (Sardinops sagax). Canadian Journal of Fisheries and Aquatic Sciences 52:566-577 
King HR, Pankhurst NW, Watts M, Pankhurst PM (2003) Effect of elevated summer temperatures on gonadal steroid production, vitellogenesis and egg quality in female Atlantic salmon. Journal of Fish Biology 63:153-167

Kingsford $M$ and Finn $M$ (1997) The influence of phase of the moon and physical processes on the input of presettlement fishes to coral reefs. Journal of Fish Biology 51A:176-205

Kiørboe T and Nielsen TG (1994) Regulation of zooplankton biomass and production in a temperate, coastal ecosystem. Limnology and Oceanography 39:493-507

Laidig TE, Chess JR, and Howard DF (2007) Relationship between abundance of juvenile rockfishes (Sebastes spp.) and environmental variables documented off northern California and potential mechanisms for the covariation. Fisheries Bulletin 105:39-48

Landry MR (1978) Population dynamics and production of a planktonic marine copepod, Acartia clausii, in a small temperate lagoon on San Juan Island, Washington. Internationale Revue der gesamten Hydrobiologie und Hydrographie 63:77-119 Leggett WC and DeBlois E (1994) Recruitment in marine fishes: is it regulated by starvation and predation in the egg and larval stages? Netherlands Journal of Sea Research 32:119-134

Leis JM and McCormick MI (2002) The biology, behavior, and ecology of the pelagic, larval stage of coral reef fishes. Academic Press, San Diego, CA, p. 171-199

Leising AW, Schroeder ID, Bograd SJ, Bjorkstedt EP, Field J, Sakuma K and Peterson J (2014) State of the California Current 2013-14: El Nino looming. California Cooperative Oceanic Fisheries Investigations Reports 55:51-87

Leising AW, Schroeder ID, Bograd SJ, Peterson WT, Brodeur RD, Santora JA, Sydeman WJ and Warybok P (2015) State of the California Current 2014 - 15: Impacts of the warmwater "Blob." California Cooperative Oceanic Fisheries Investigations Reports 56:31-58

Liboschik T, Fokianos K, and Fried R (2016) tscount: An R package for analysis of count time series following generalized linear models. Vignette of $R$ package tscount version 1.3.0.

Litvak MK and Leggett WC (1992) Age and size-selective predation on larval fishes, the bigger-is-better hypothesis revisited. Marine Ecology Progress Series 81:13-24

Logerwell E and Smith P (2001) Mesoscale eddies and survival of late stage Pacific sardine (Sardinops sagax) larvae. Fisheries Oceanography 10:13-25

McCormick MI and Molony BW (1995) Influence of water temperature during the larval stage on size, age and body condition of a tropical reef fish at settlement. Marine Ecology Progress Series 118:59-68 
McFarland WN, Brothers EB, Ogden JC, Schulman MJ, Bermingham EL, and KotchianPrentiss NM (1985) Recruitment patterns in young French grunts, Haemulon lavolineatum (family Haemulidae), at St. Croix, Virgin Islands. U.S. Fisheries Bulletin 83:413-426

McGowan JA, Bograd SJ, Lynn RJ, and Miller AJ (2003) The biological response to the 1977 regime shift in the California Current. Deep Sea Research, Part II 50:2567-2582

McGurk MD (1984) Effects of delayed feeding and temperature on the age of irreversible starvation and on the rates of growth and mortality of Pacific herring larvae. Marine Biology 84:13-26

Meekan MG, Fortier L (1996) Selection for fast growth during the larval life of Atlantic cod Gadus morhua on the Scotian Shelf. Marine Ecology Progress Series 137:25-37

Mendelssohn R (2015) Xtractomatic: extracts environmental data from ERD's ERDDAP web service. https://github.com/rmendels/xtractomatic

Milicich MJ (1994) Dynamic coupling of reef fish replenishment and oceanographic processes. Marine Ecology Progress Series 110:135-144

Miller EF and Allen LG (2006) Captive breeding of spotted sand bass, Paralabrax maculatofasciatus, in southern California. California Fish and Game 92:98-105

Miller TJ, Crowder LB, Rice JA, and Marschall EA (1988) Larval size and recruitment mechanisms in fishes: toward a conceptual framework. Canadian Journal of Fisheries and Aquatic Science 45:1657-1670

Miller GM, Kroon F, Metcalfe S, Munday P (2015) Temperature is the evil twin: Effects of increased temperature and ocean acidification on reproduction in a reef fish. Ecological Applications 25:603-620

Morse WW (1989) Catchability, growth, and mortality of larval fishes. United States National Marine Fisheries Service Fishery Bulletin 87:417-446

Moser HG, Charter RL, Smith P, Ambrose DA, Watson W, Charter SR, Sandknop EM (2001) Distributional atlas of fish larvae and eggs in the Southern California Bight region: 1951-1998. California Cooperative Oceanic Fisheries Investigations Atlas 34:1-166

Moser HG, Charter RL, Watson W, Ambrose DA, Butler JL, Charter SR, Sandknop EM (2000) Abundance and distribution of rockfish (Sebastes) larvae in the Southern California Bight in relation to environmental conditions and fishery exploitation. California Cooperative Oceanic Fisheries Investigations Reports 41:132-147

Navarrete SA, Broitman B, Wieters EA, Finke GR, Venegas RM, Sotomayor A (2002) Recruitment of intertidal invertebrates in the southeast Pacific: Interannual variability and the 1997-1998 El Nino. Limnology and Oceanography 47:791-802 
Nixon SW, Granger S, Buckley B, Lamont M, and Rowell B (2004) A one hundred and seventeen year coastal water temperature record from Woods Hole, MA. Estuaries and Coasts 27:1-8

Oda DL, Lavenberg RJ, and Rounds JM (1993) Reproductive biology of three California species of Paralabrax (Pisces: Serranidae). California Cooperative Oceanic Fisheries Investigations 34:122-132

Paulsen M, Clemmesen C, and Malzahn AM (2014) Essential fatty acid (docosahexaenoic acid, DHA) availability affects growth of larval herring in the field. Marine Biology 161:239-244

Peck MA, Baumann H, Clemmesen C, Herrmann J-P, Moyano M, Temming A (2015) Calibrating and comparing somatic-, nucleic acid-, and otolith-based indicators of growth and condition in young juvenile European sprat (Sprattus sprattus). Journal of Experimental Marine Biology and Ecology 471:217-225

Pepin P, Shears TH, and de Lafontaine $Y$ (1992) Significance of body size to the interaction between a larval fish (Mallotus villosus) and a vertebrate predator (Gasterosteus aculeatus). Marine Ecology Progress Series 81:1-12

Pollock BR, Weng H, and Morton RM (1983) The seasonal occurrence of post larval stages of yellowfin bream (Acanthopagrus australis) and some factors affecting their movement into an estuary. Journal of Fisheries Biology 22:409-416

Quast JC (1968) Observations on the food and biology of the kelp bass, Paralabrax clathratus, with notes on its sportfishery at San Diego, California. California Fish and Game Fish Bulletin 139:81-108

Ralston S, Sakuma KM, and Field JC (2013) Interannual variation in pelagic juvenile rockfish (Sebastes spp.) abundance: going with the flow. Fisheries Oceanography 22:288-308

Rana KJ (1985) Influence of egg size on the growth, onset of feeding, point-of-no-return, and survival of unfed Oreochromis mossambicus fry. Aquaculture 46:119-131

Randall JE (1961) A contribution to the biology of the convict surgeonfish of the Hawaiian Islands, Acanthurus triostegus sandvicensis. Pacific Science 15:215-272

Rankin TL, Sponaugle S (2011) Temperature influences selective mortality during the early life stages of a coral reef fish. PLoS ONE 6:1-9

Rankin TL, Sponaugle S (2014) Characteristics of settling coral reef fish are related to recruitment timing and success. PLOS ONE 9:1-13

Reyns N, Sponaugle S (1999) Patterns and processes of brachyruran crab settlement to Caribbean coral reefs. Marine Ecology Progress Series 185:155-170 
Rhodes KL (2012) Species case studies: camouflage grouper - Epinephelus polyphekadion. Reef fish Spawning Aggregations: Biology, Research and Management $p$. 422-428

Robert D, Castonguay M, and Fortier L (2007) Early growth and recruitment in Atlantic mackerel: discriminating the effects of fast growth and selection for fast growth. Marine Ecology Progress Series 337:209-219

Robertson DR, Green DG, Victor BC (1987) Relations in the lunar periodicities of larval production and settlement by a Caribbean reef fish. Bulletin of Marine Science 41:641

Schirripa MJ, Colbert JJ (2006) Interannual changes in sablefish (Anoplopoma fimbria) recruitment in relation to oceanographic conditions within the California Current System. Fisheries Oceanography 15:25-36

Schmitt RJ, and Holbrook SJ (2002) Spatial variation in concurrent settlement of three damselfishes: relationships with near-field current flow. Oecologia 131:391-401

Searcy SP, Sponaugle S (2000) Variable larval growth in a coral reef fish. Marine Ecology Progress Series 206:213-226

Searcy SP, Sponaugle SU (2001) Selective mortality during the larval-juvenile transition in two coral reef fishes. Ecology 82:2452-2470

Searcy SP, Eggleston DB, Hare JA (2007) Is growth a reliable indicator of habitat quality and essential fish habitat for a juvenile estuarine fish? Canadian Journal of Fisheries and Aquatic Sciences 64:681-691 Seekall DA, and Pace ML (2011) Climate change drives warming in the Hudson River Estuary, New York (USA). Journal of Environmental Monitoring 13:2321-2327

Soto-Mendoza S, Parada C, Castro L, Colas F, Schneider W (2012) Modeling transport and survival of anchoveta eggs and yolk-sac larvae in the coastal zone off centralsouthern Chile: Assessing spatial and temporal spawning parameters. Progress in Oceanography 29:178-191

Sponaugle S, Grorud-Colvert K, Pinkard D (2006) Temperature-mediated variation in early life history traits and recruitment success of the coral reef fish Thalassoma bifasciatum in the Florida Keys. Marine Ecology Progress Series 308:1-15

Stephens, JS, Morris PA, Pondella DJ, Koonce TA, Jordan GA (1994) Overview of the Dynamics of an Urban Artificial Reef Fish Assemblage at King Harbor, California, USA, 1974-1991: A Recruitment driven system. Bulletin of Marine Science 55:1224-1239

Takahashi M, Watanabe Y (2005) Effects of temperature and food availability on growth rate during late larval stage of Japanese anchovy (Engraulis japonicus) in the KuroshioOyashio transition region. Fisheries Oceanography 14:223-235 
Vargas CA, Valenzuela GS, and Arcos DF (1998) Role of oceanographic topographic factors in the retention of hake (Merluccius gayi gayi Guichenot, 1848) larvae in the upwelling system off central-southern Chile. Archive of Fishery and Marine Research 45:201-222

Voss R, Clemmesen C, Baumann H, Hinrichsen HH (2006) Baltic sprat larvae: coupling food availability, larval condition and survival. Marine Ecology Progress Series 308:243254

Watson JR, Mitarai S, Siegel DA, Caselle JE, Dong C, McWilliams JC (2010) Realized and potential larval connectivity in the southern California bight. Marine Ecology Progress Series 401:31-48

Wei F, Wu Y, Cui X (2009) The study on fishing ground of neon flying squid, Ommastrephes bartrami, and ocean environment based on remote sensing data in the Northwest Pacific Ocean. Chinese Journal of Oceanology and Limnology 27:408-414

Whitney FA (2015) Anomalous winter winds decrease 2014 transition zone productivity in the NE Pacific. Geophysical Research Letters 42:428-431

Wilson JR, Broitman BR, Caselle JE, Wendt DE (2008) Recruitment of coastal fishes and oceanographic variability in central California. Estuarine, Coastal and Shelf Science 79:483-490

Wing SR, Botsford LW, Morgan LE, Diehl JM, and Lundquist CJ (2003) Inter-annual variability in larval supply to populations of three invertebrate taxa in the northern California Current. Estuarine, Coastal and Shelf Science 57:859-872

Witman JD, Leichter JJ, Genovese SJ, and Brooks DA (1993) Pulsed phytoplankton supply to the rocky subtidal zone: influence of internal waves. Proceedings of the National Academy of Sciences of the USA 90:1686-1690

Woodson CB, McManus MA, Tyburczy J, Barth JA, Washburn L, Raimondi PT, Menge BA, and Palumbi SR (2012a) Persistent fronts structure connectivity patterns along the Eastern Pacific. Limnology and Oceanography 57:582-596

Woodson CB, McManus MA, Tyburczy JA, Barth JA, Washburn L, Caselle JE, Carr MH, Malone DP, Raimondi PT, Menge BA, and Palumbii SR (2012b) Coastal fronts set recruitment and connectivity patterns across multiple taxa. Limnology and Oceanography 57:582-596

Wootton RJ (1990) Ecology of teleost fishes. Chapman \& Hall, London p. 404

Zabel RW, Levin PS, Tolimieri M, and Mantua NJ (2011) Interactions between climate and population density in the episodic recruitment of bocaccio, Sebastes paucispinis, a Pacific rockfish. Fisheries Oceanography 20:294-304 
Zimmerman RC, and Kremer JN (1984) Episodic nutrient supply to a kelp forest ecosystem in Southern California. Journal of Marine Research 42:591-604 
Figure 1. Map of Mission Bay and surrounding area, including wave height collection buoy (black circle, $32^{\circ} 44^{\prime} 48^{\prime \prime} \mathrm{N} 117^{\circ} 22^{\prime} 12^{\prime \prime} \mathrm{W}$ ), location of fish collectors (black square, $32^{\circ} 45^{\prime} 52^{\prime \prime} \mathrm{N} 117^{\circ} 14^{\prime} 32^{\prime \prime} \mathrm{W}$ ), and San Diego Airport (black triangle, $32^{\circ} 43^{\prime} 58^{\prime \prime} \mathrm{N}$ $117^{\circ} 11^{\prime} 48^{\prime \prime}$ W). Inset shows California (CA) with location of Mission Bay (black square) in California, USA. 


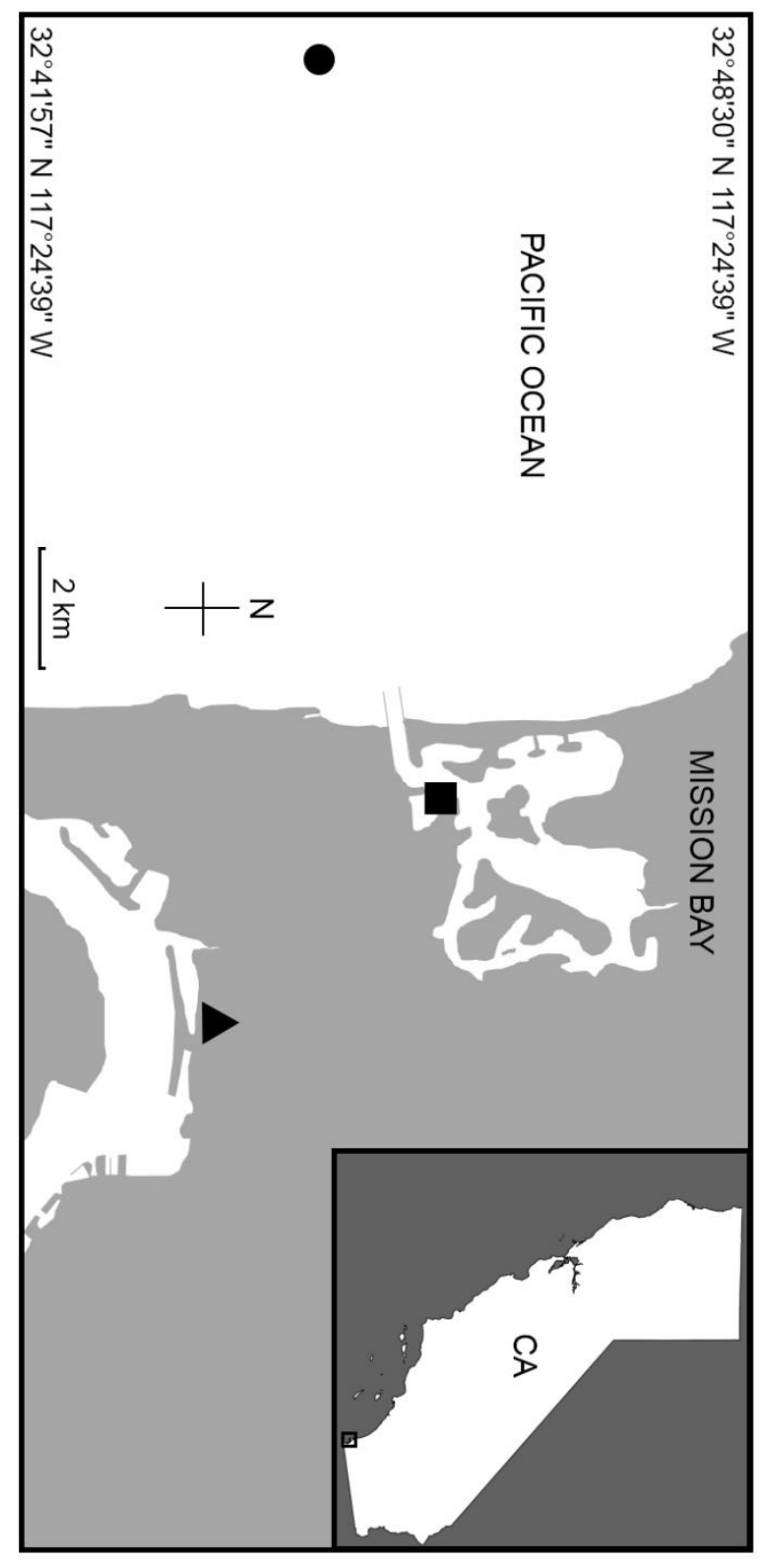


Figure 2. Diagram of settling fish collector, a plastic mesh cylinder containing giant kelp (Macrocystis pyrifera) with Styrofoam float and concrete anchor. 


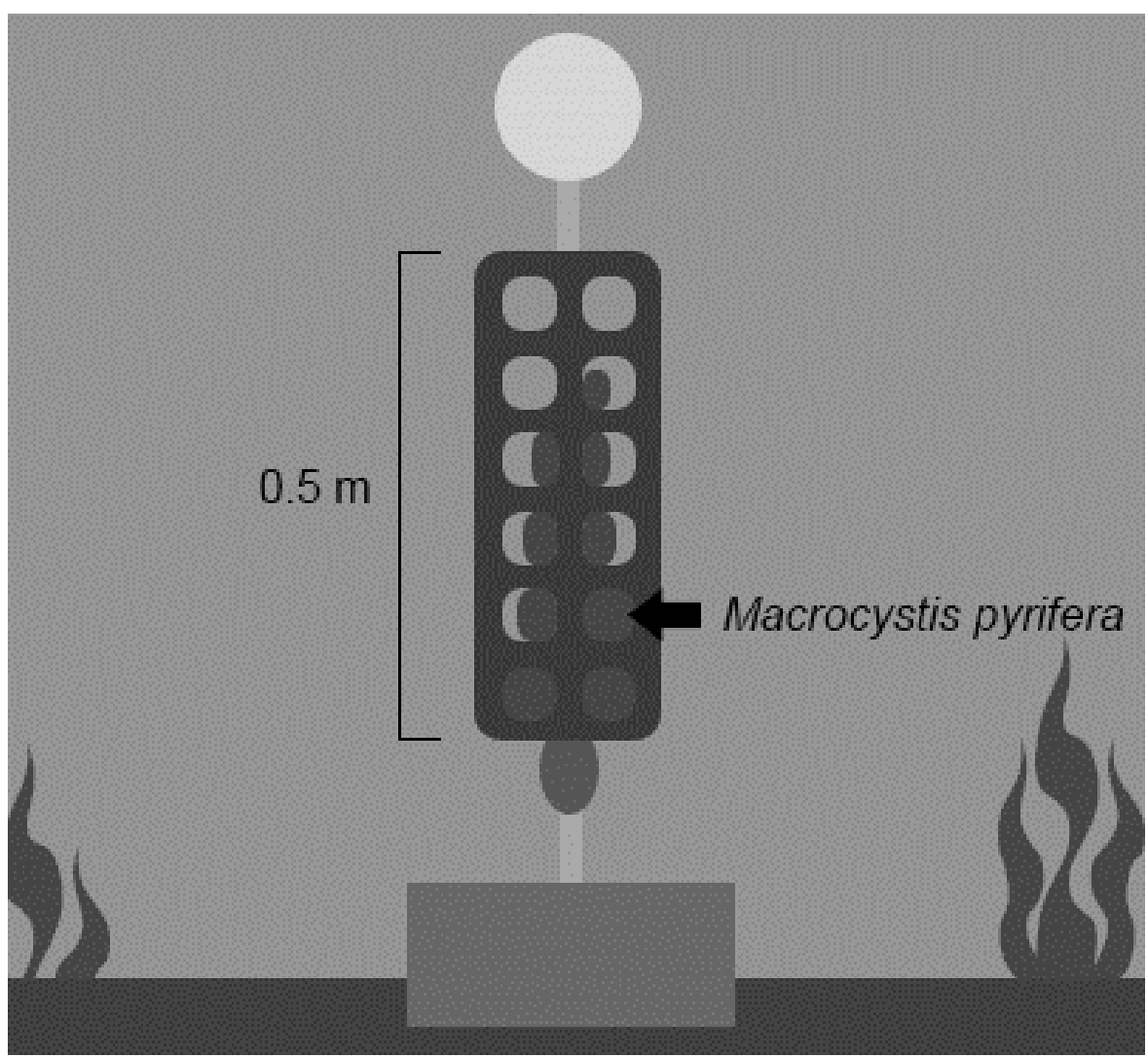


Figure 3. Digital image of a sagittal otolith, with settlement check indicated by black arrow. Otolith increments on either side of the settlement check have been highlighted by black lines. 


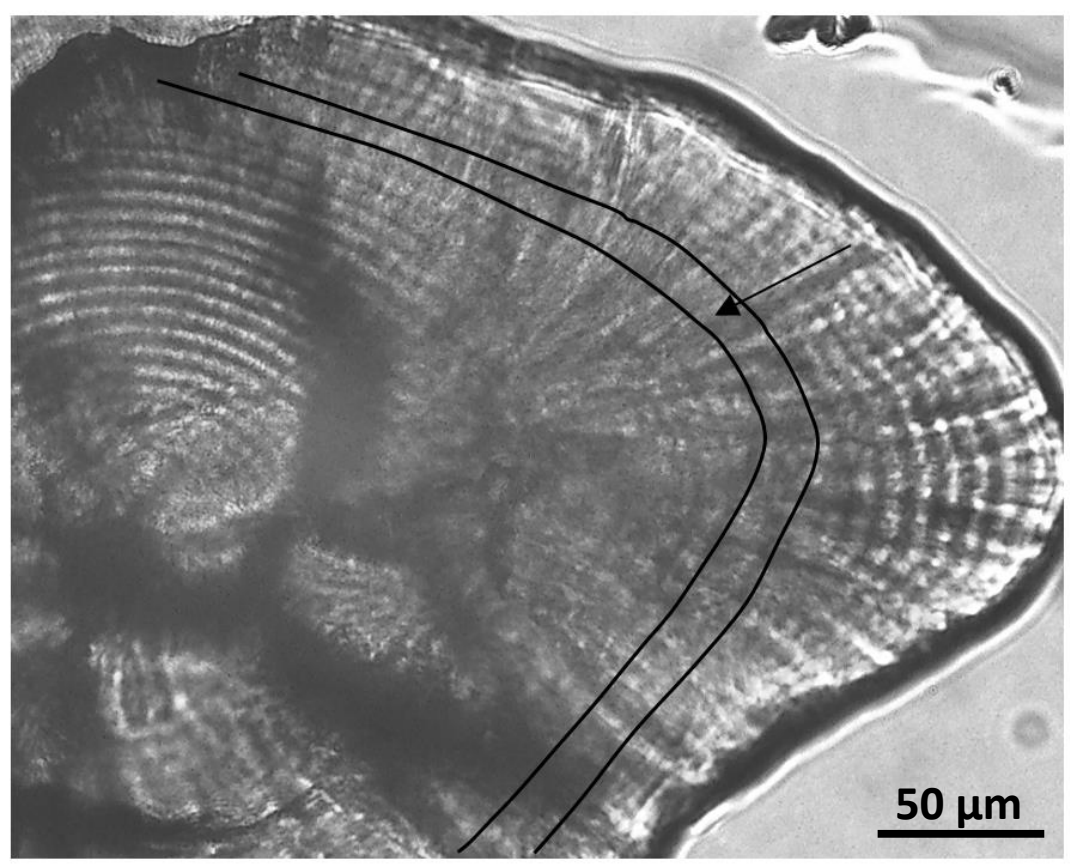


Figure 4. Scatterplot of age at collection and standard length at collection for all $P$.

maculatofasciatus larvae collected. The equation of the line $(y=0.1747 x+4.553)$ was used to back calculate standard length at settlement. 


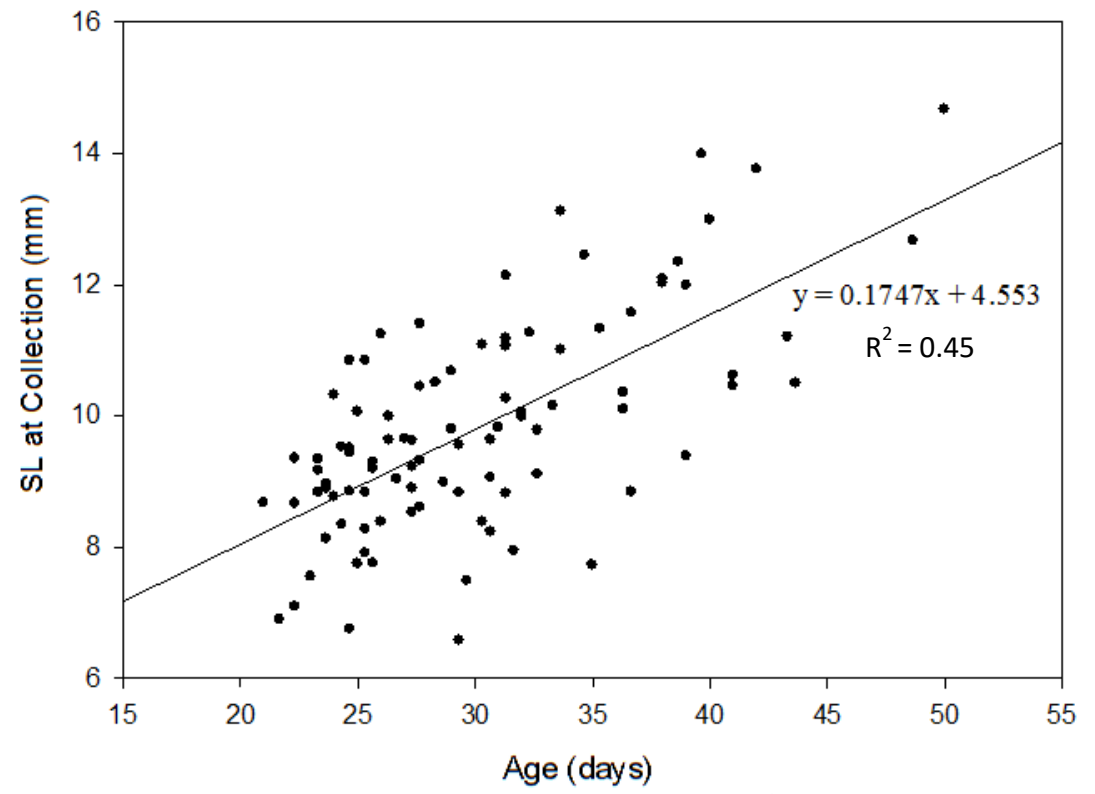


Figure 5. Potential area, designated by bold box surrounding the southern California and northern Baja California coast, from which spotted sand bass larvae may travel to settle in Mission Bay (black star). Location where upwelling index and alongshore Ekman transport data were collected is indicated by the black circle. 


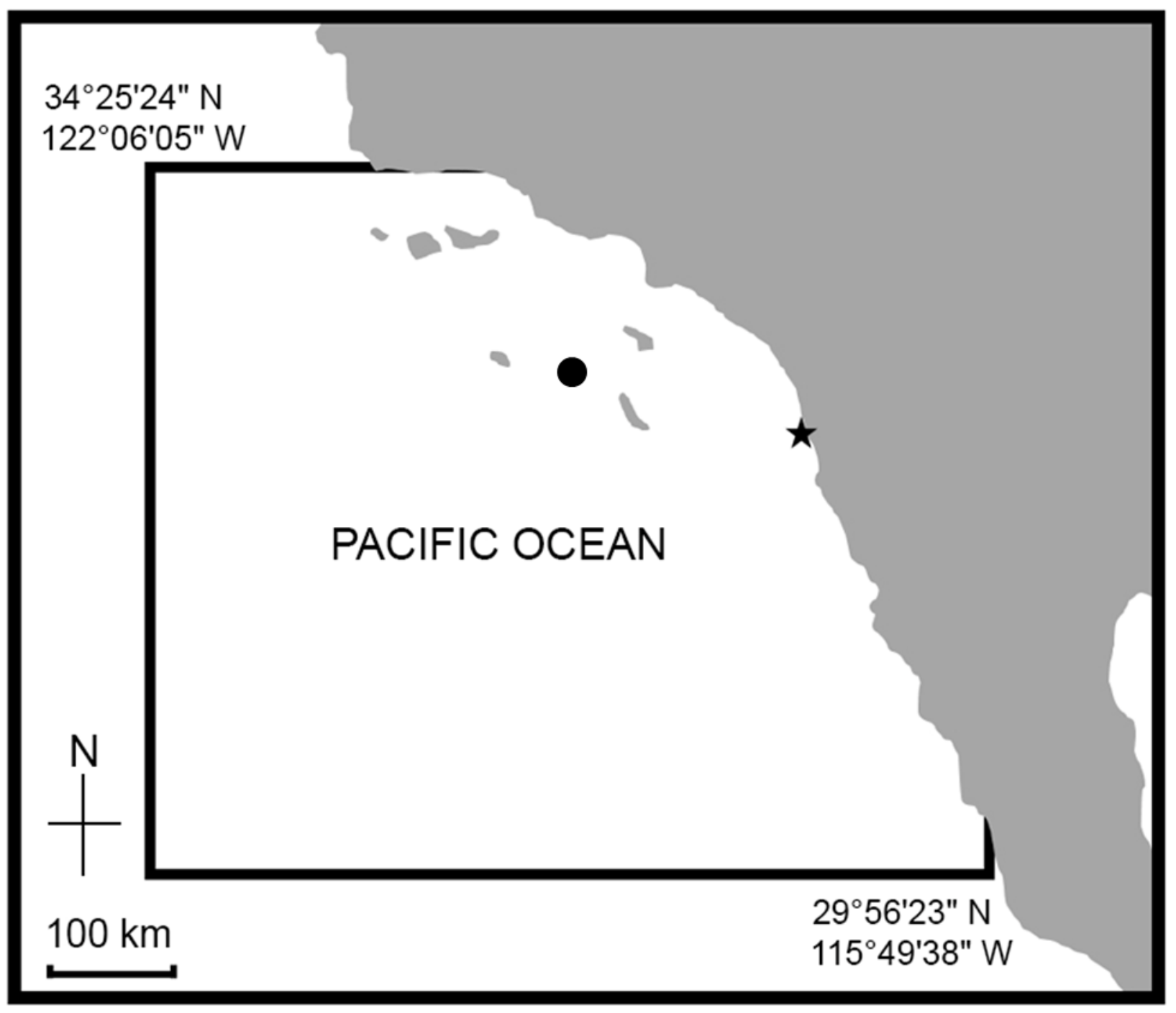


Figure 6. Annual mean proportion of settlement for each lunar day. White and black circles indicate full and new moon, respectively. 


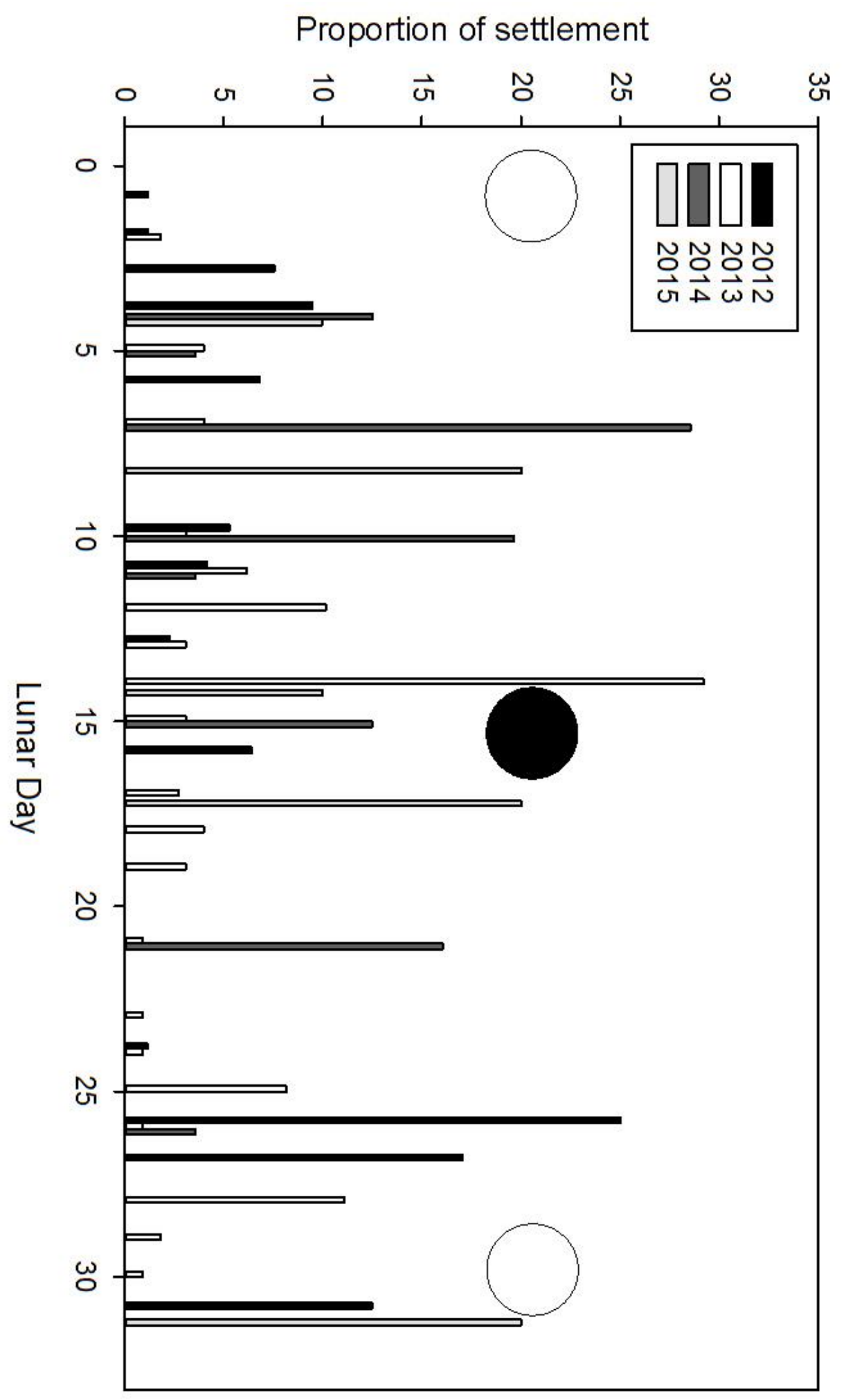


Figure 7. Annual mean abundance of spotted sand bass $( \pm S E)$ collected each year, based on daily settlement samples using settlement dates back-calculated from otoliths. Total fish collected are displayed above error bars. Identical letters indicate means that are not significantly different from one another (Kruskal-Wallis: $X^{2}=14.81, d f=6, p=$ $0.022)$. 


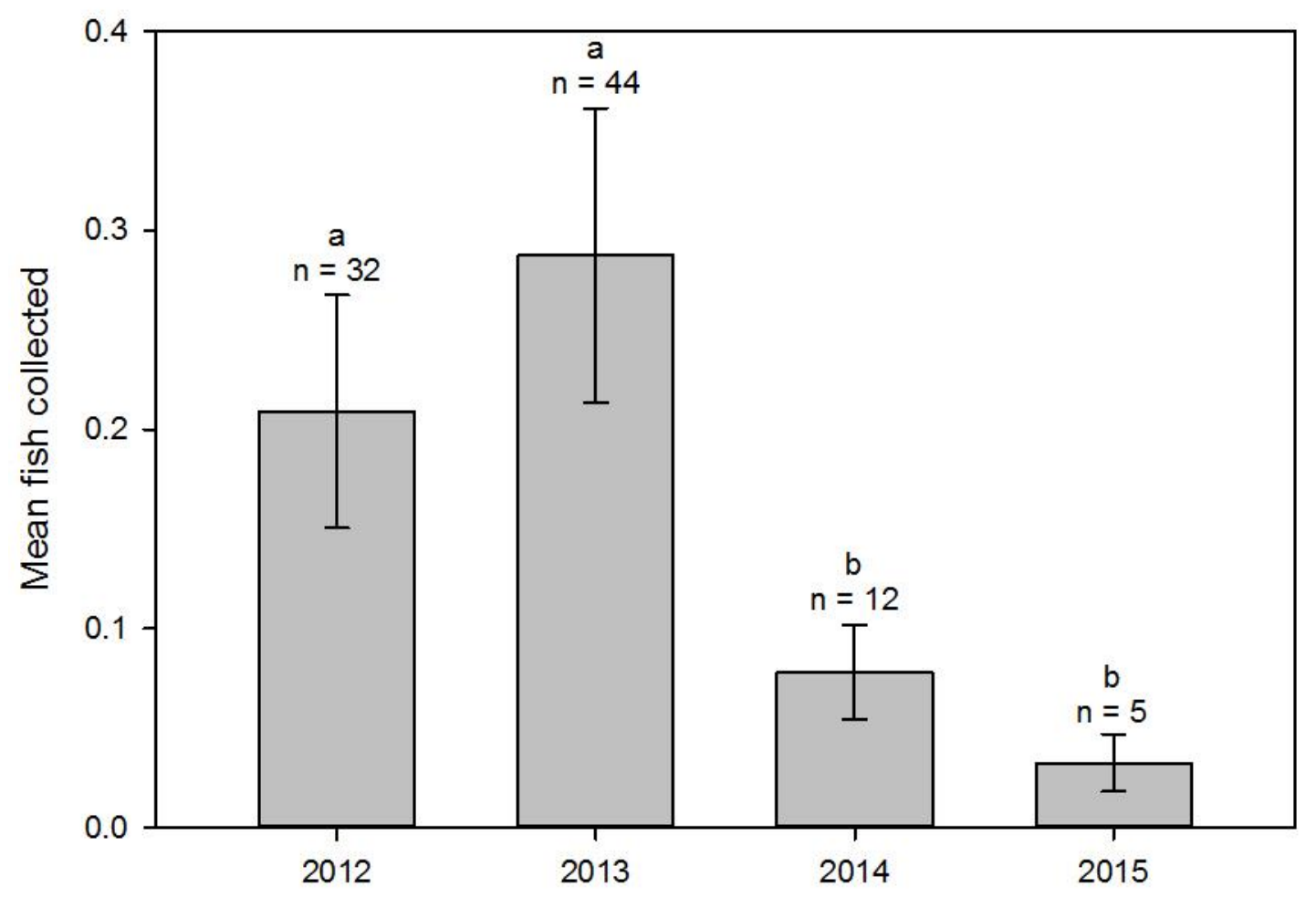


Figure 8. Mean standard length $( \pm \mathrm{SE}$ ) of spotted sand bass at time of settlement (a) and collection (b) by year. Standard length (SL) at settlement was calculated using linear regression (Fig. 4). Fish were significantly shorter at settlement in 2012, with a trend of longer fish in 2014-15 (a, ANOVA: $F=15.93, d f=1, p=0.00013$ ). Fish in 2014-15 had significantly longer $S L$ at time of collection ( $b$, ANOVA: $F=9.09, d f=3, p=0.003$ ). Identical letters indicate means that are not significantly different from one another. 

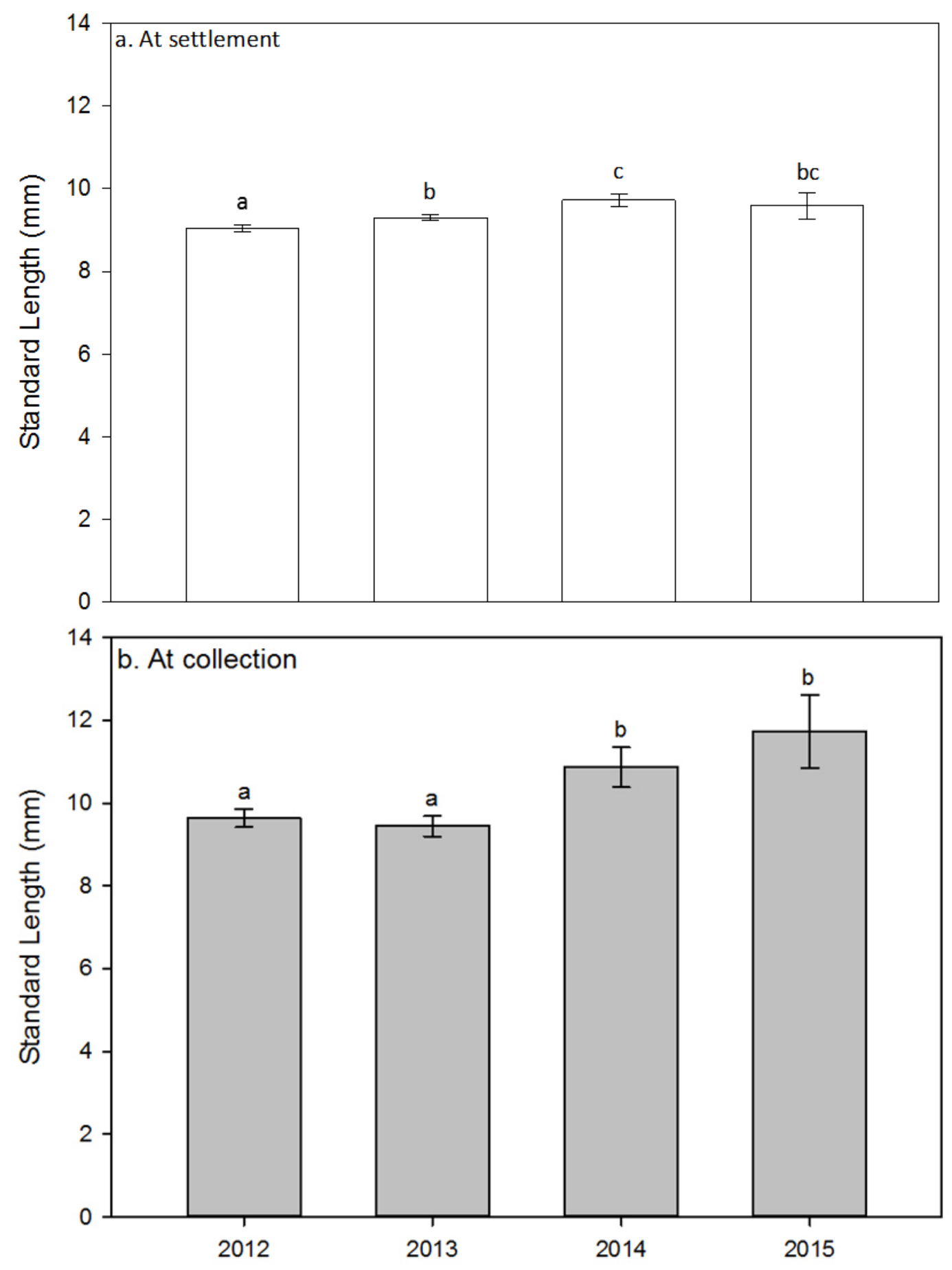
Figure 9. Mean body condition ( \pm SE) for all spotted sand bass collected in a given year. Identical letters indicate means that are not significantly different from one another (Kruskal-Wallis: $\mathrm{X}^{2}=79.13, \mathrm{df}=6, \mathrm{p}=0.00022$ ). 


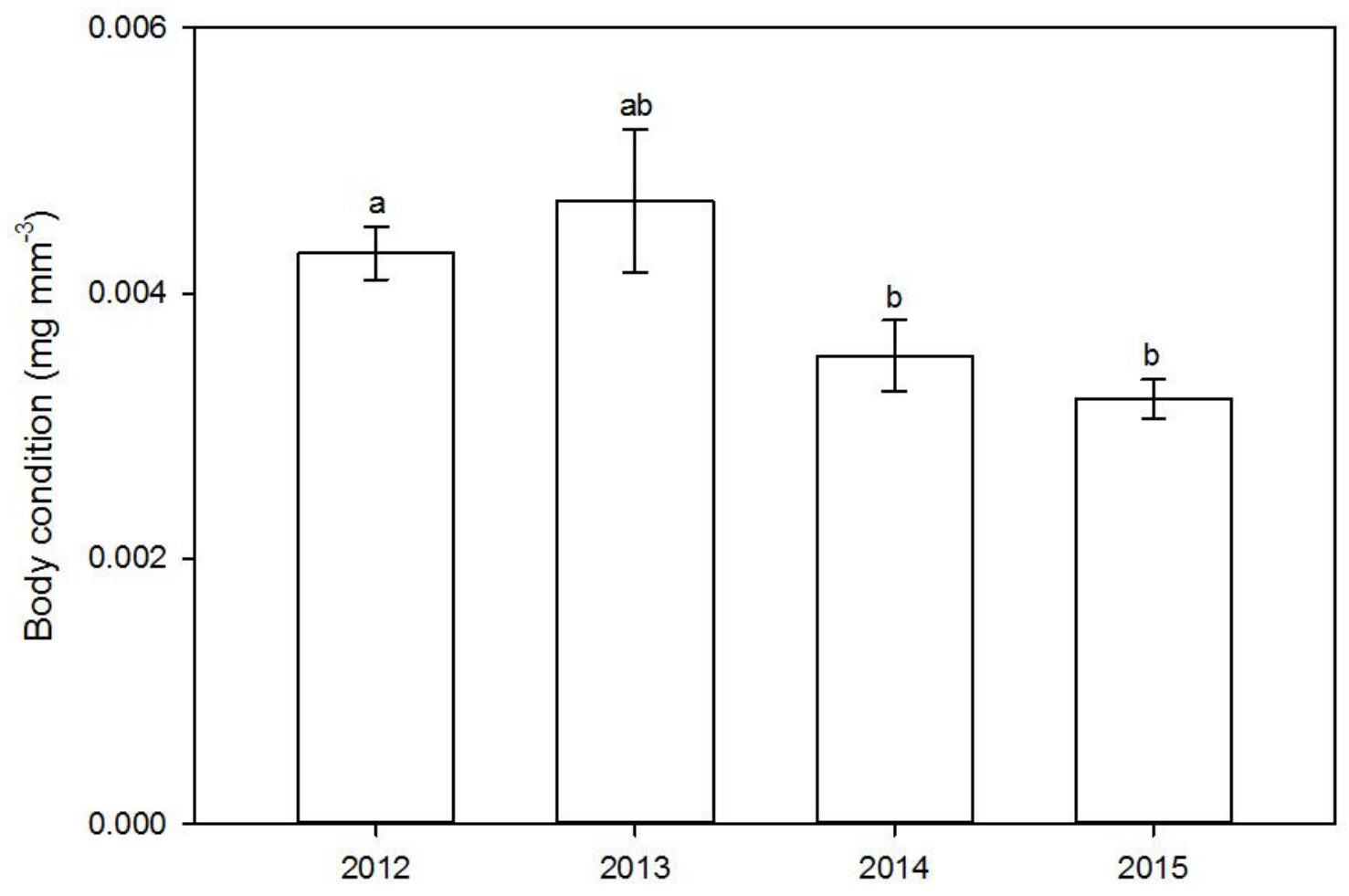


Figure 10. Mean pelagic larval duration $( \pm S E$ ) for all spotted sand bass of a given year. Identical letters indicate means that are not significantly different from one another (ANOVA: $F=15.93, d f=3, p=0.00013$ ). 


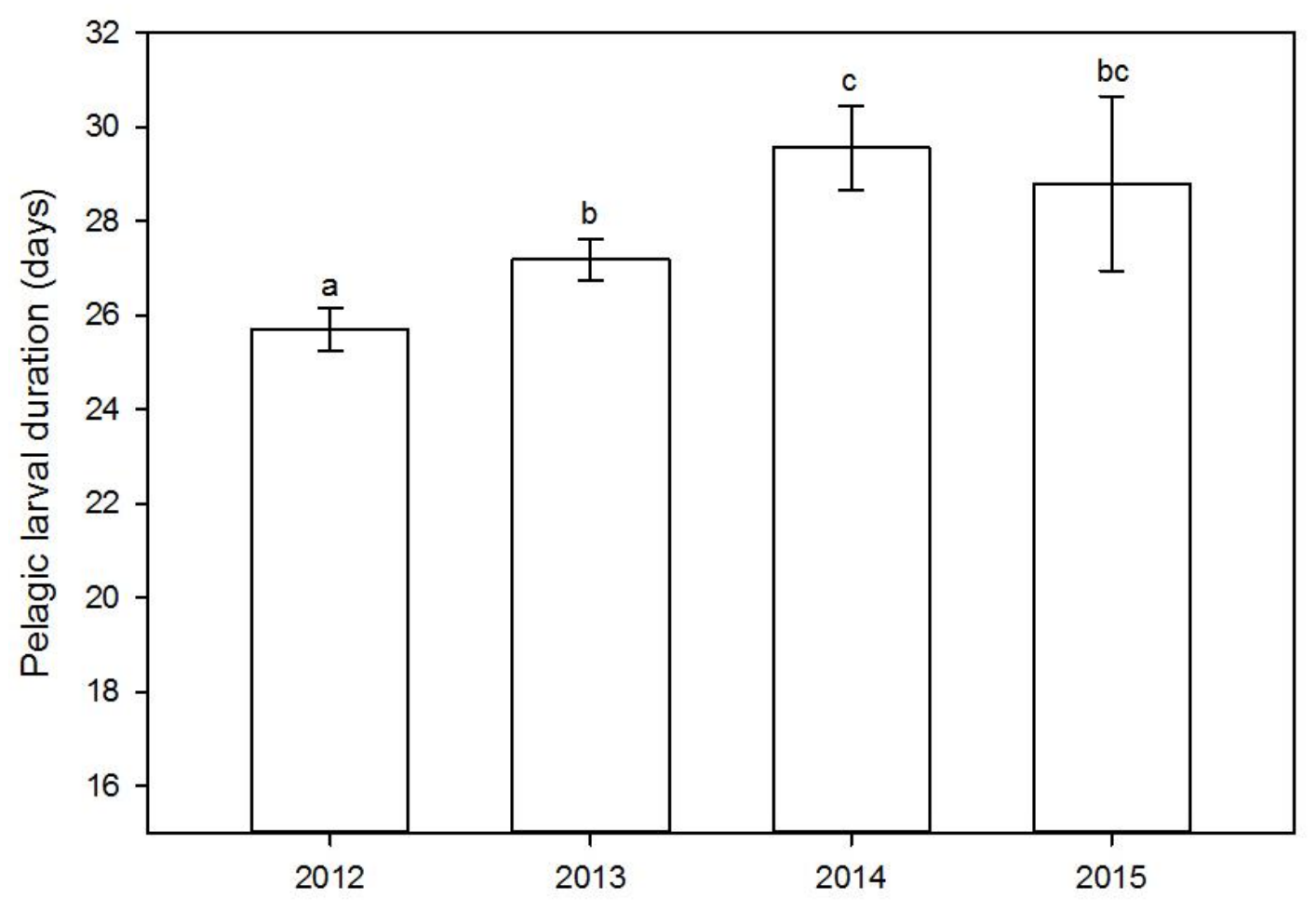


Figure 11. Mean otolith growth $( \pm \mathrm{SE}$ ) for all spotted sand bass of a given year. Identical letters indicate means that are not significantly different from one another (KruskalWallis: $F=37.82, d f=2, p=6.12$ e-09). 


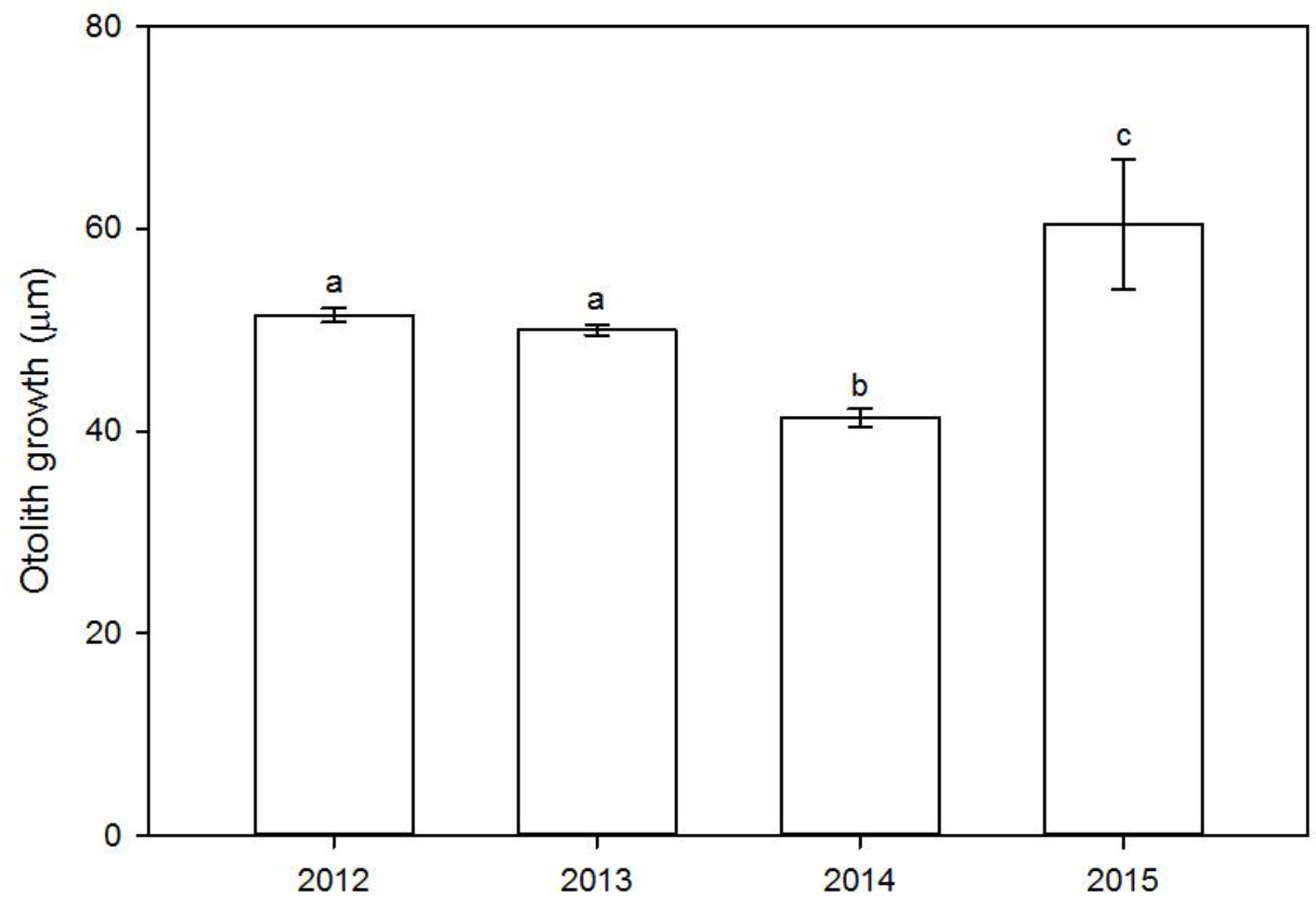


Figure 12. Mean annual sea surface temperature $( \pm \mathrm{SE})$, from May - October. Identical letters indicate means that are not significantly different from one another (KruskalWallis: $X^{2}=56.82, d f=3, p=0.0062$. 


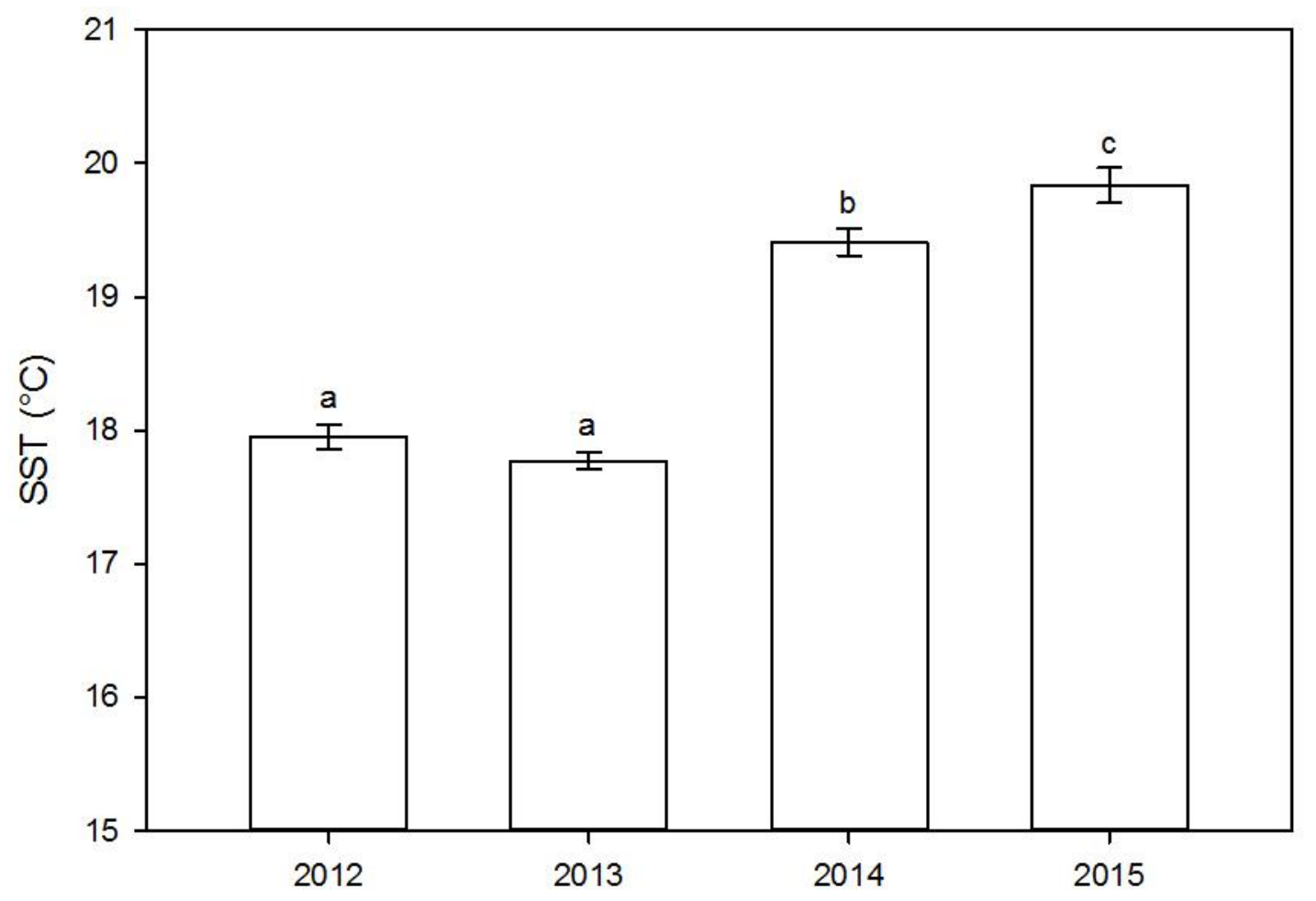


Figure 13. Mean annual wind speed $( \pm \mathrm{SE})$ from May-October. Calculated from 24 hourly averages taken each day. Identical letters indicate means that are not significantly different from one another (Kruskal-Wallis: $X^{2}=7.098, d f=10, p=0.035$ ). 


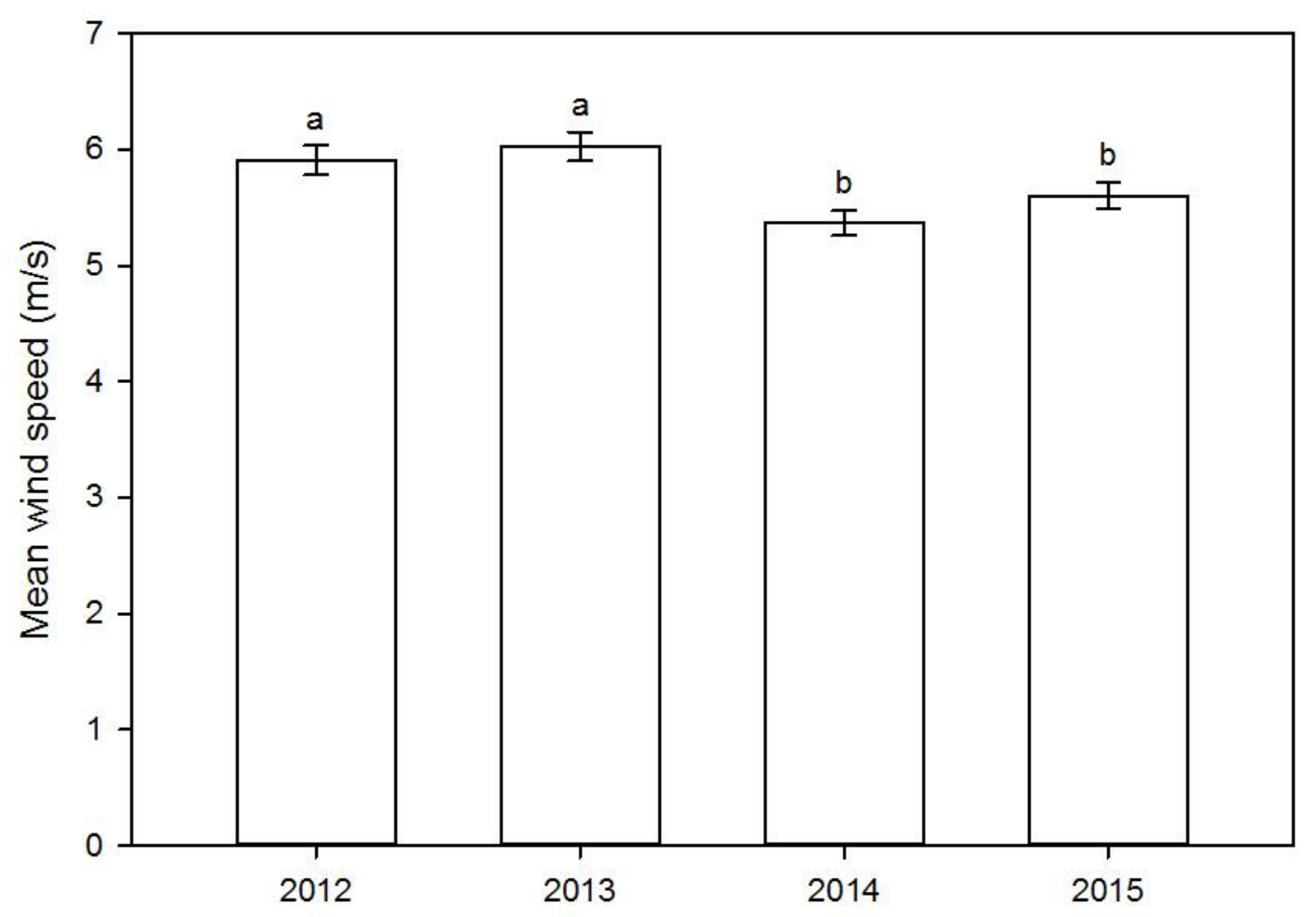


Figure 14. Mean annual upwelling index $( \pm$ SE) from May - October. Calculated from daily averages of four 6 hourly measurements. Identical letters indicate means that are not significantly different from one another (Kruskal-Wallis: $X^{2}=468.3, d f=446, p=$ $0.02)$. 


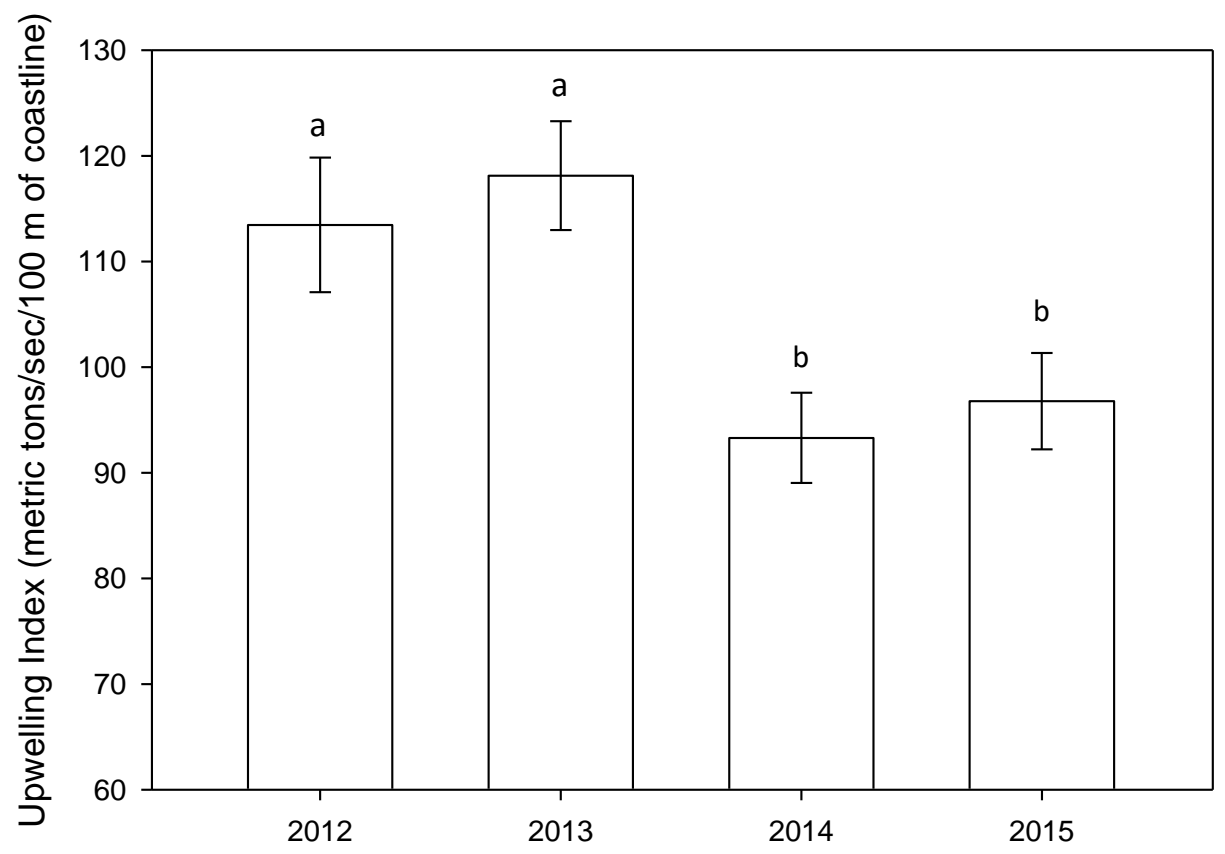


Figure 15. Mean alongshore Ekman transport $( \pm \mathrm{SE})$ from May - October. Calculated from daily averages of four 6 hourly measurements. Identical letters indicate means that are not significantly different from one another (Kruskal-Wallis: $X^{2}=301.77, \mathrm{df}=282, \mathrm{p}$ $=0.09$ ). 


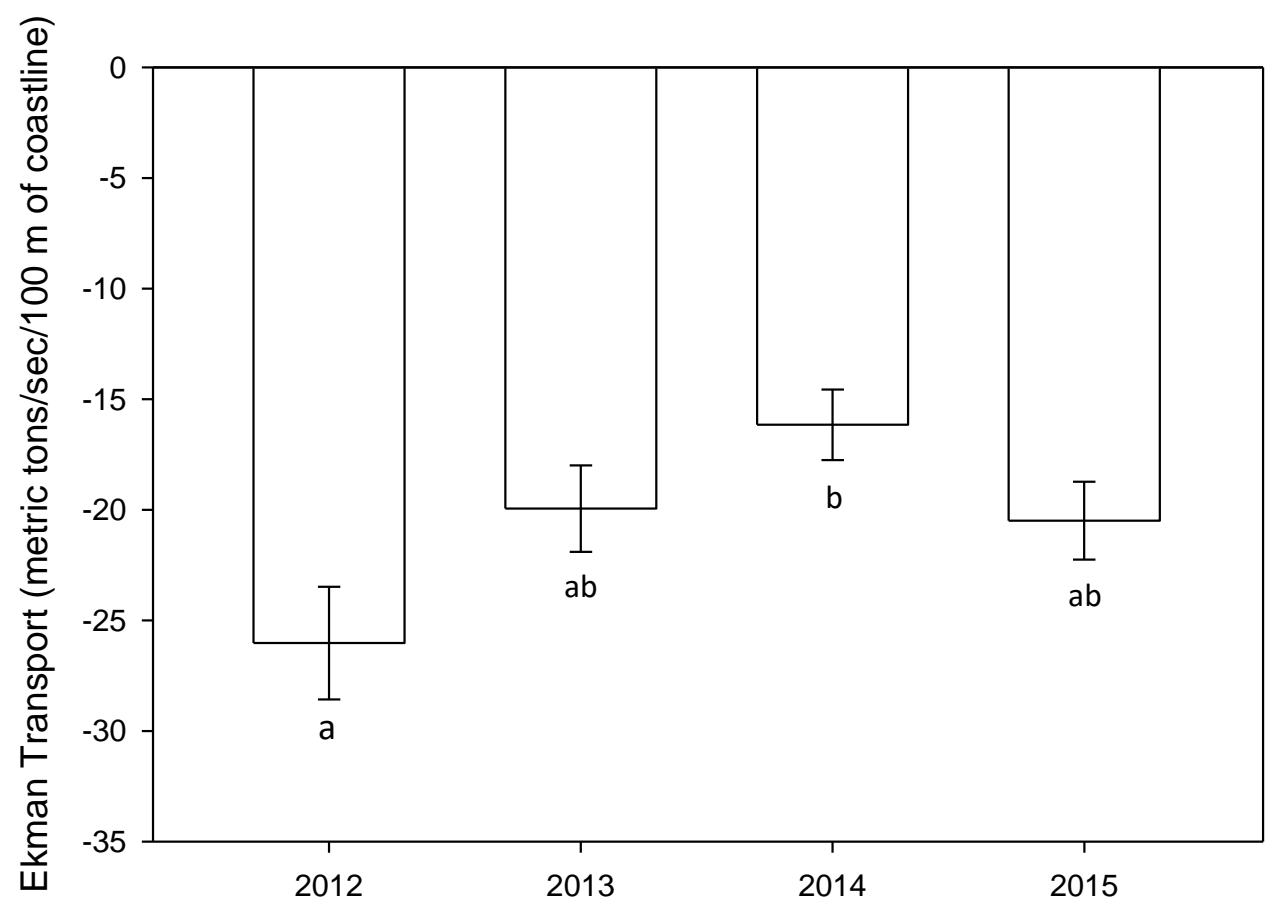


Figure 16. Mean annual sea surface chlorophyll a concentration ( \pm SE) from May October. Identical letters indicate means that are not significantly different from one another (Kruskal-Wallis: $\mathrm{X}^{2}=61.13, \mathrm{df}=3, \mathrm{p}=0.00014$ ). 


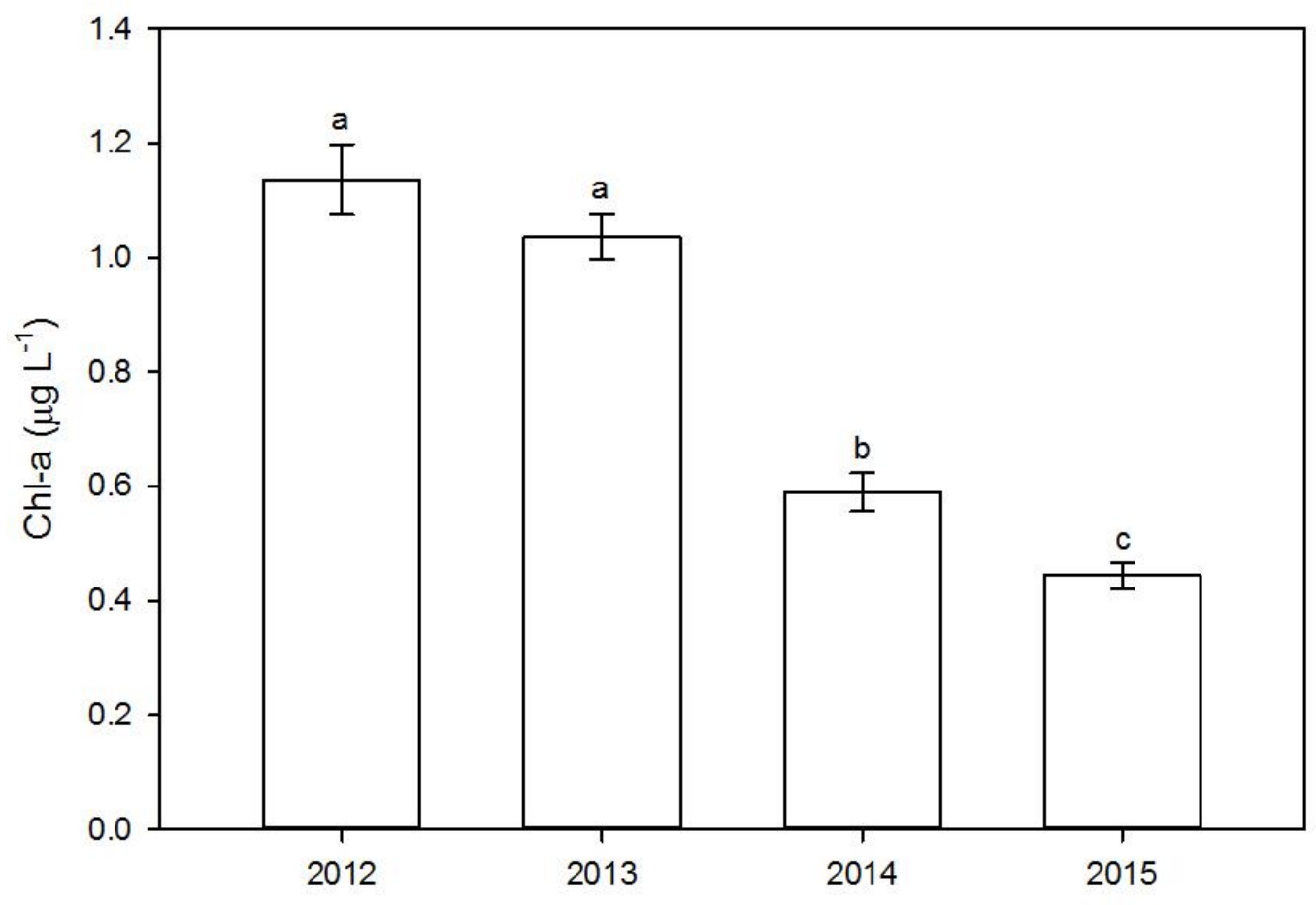


Figure 17. Mean daily sea surface chlorophyll a concentrations (black line) and total daily spotted sand bass settlement (grey bars). 

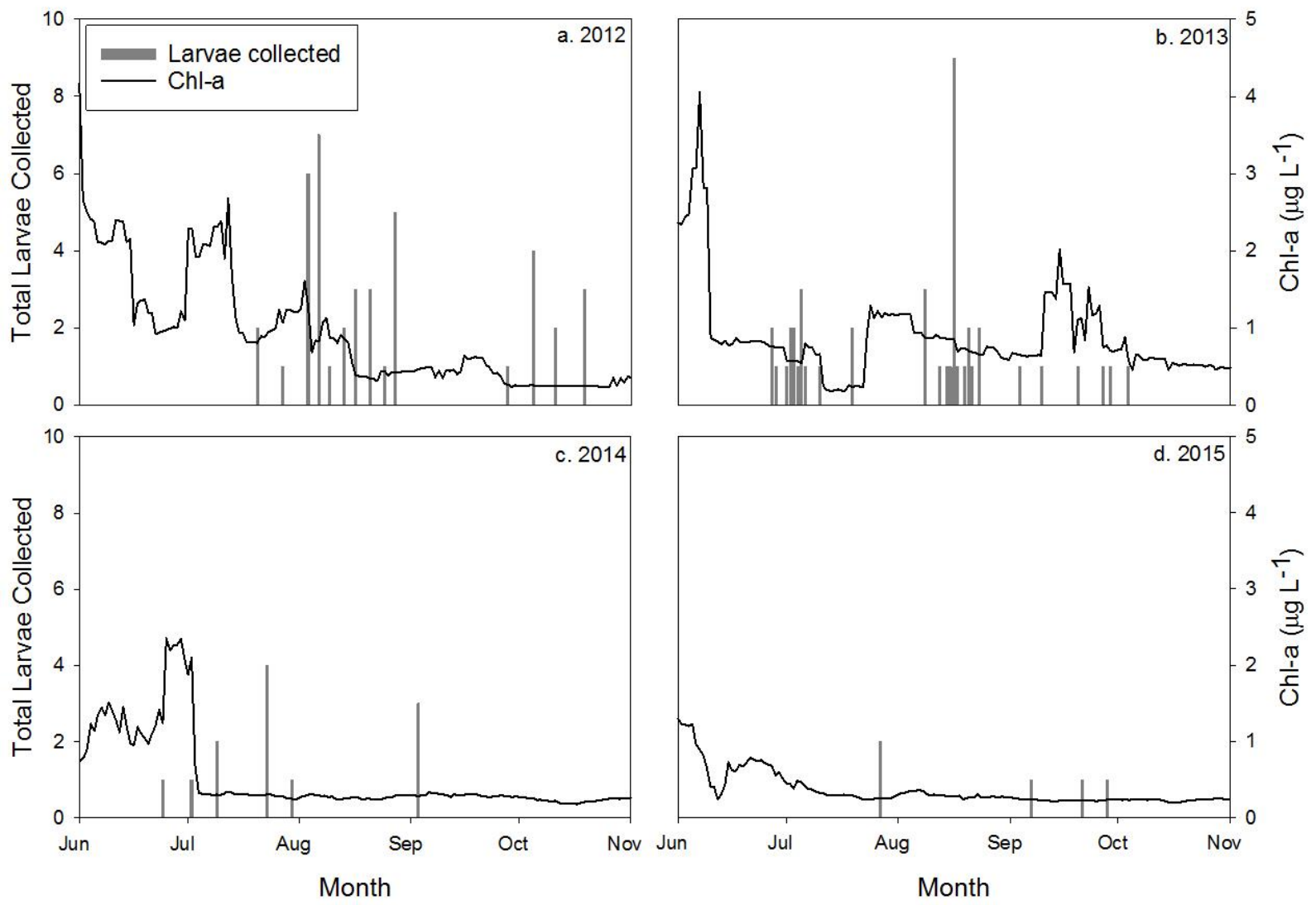
Figure 18. Mean daily sea surface temperature (SST, black line) and total daily spotted sand bass settlement (grey bars). A ten year average SST for our study area from May October has been added for reference $\left(17.9^{\circ} \mathrm{C}\right.$, dotted line). 

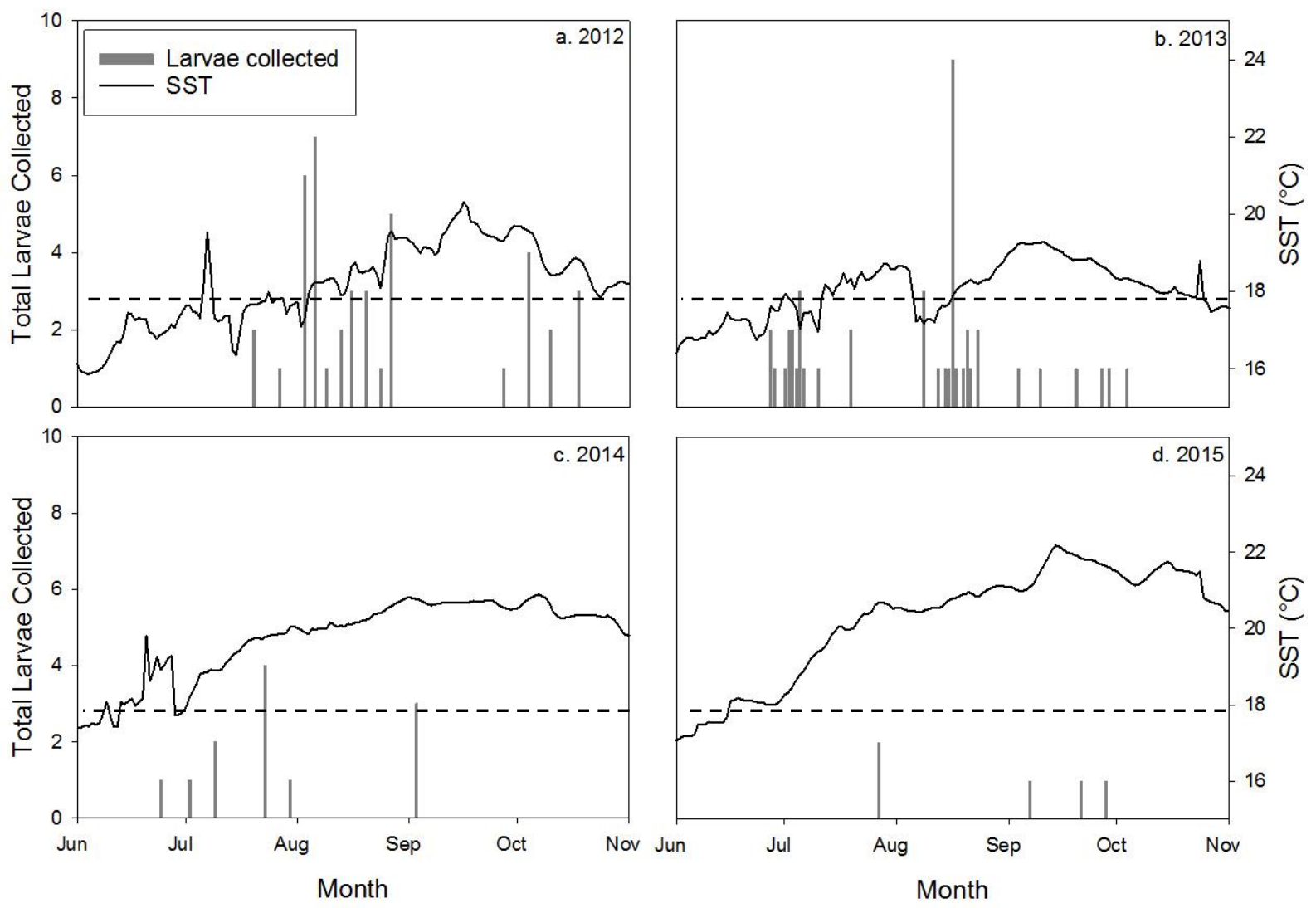
Table 1. Summary tables for environmental conditions. Means are based on data collected from May - October for each year. The buoy monitoring wave data was disrupted by a storm and not replaced during our sampling period in 2013. 


\begin{tabular}{lccccccccc}
\hline & \multicolumn{2}{c}{$\begin{array}{c}\text { SST } \\
\left({ }^{\circ} \mathrm{C}\right)\end{array}$} & \multicolumn{2}{c}{$\begin{array}{c}\text { Chl-a } \\
\left(\mu \mathrm{g} \mathrm{L}^{-1}\right)\end{array}$} & \multicolumn{2}{c}{$\begin{array}{c}\text { Wind Speed } \\
\left(\mathrm{m} \mathrm{sec}^{-1}\right)\end{array}$} & \multicolumn{2}{c}{$\begin{array}{c}\text { Wind Direction } \\
(\mathrm{deg})\end{array}$} \\
\hline Year & Mean & SE & Mean & SE & Mean & SE & Mean & SE \\
\hline $\mathbf{2 0 1 2}$ & 17.95 & 0.094 & 1.14 & 0.061 & 2.64 & 0.056 & 284.78 & 2.15 \\
\hline $\mathbf{2 0 1 3}$ & 17.77 & 0.066 & 1.037 & 0.040 & 2.69 & 0.057 & 283.97 & 2.31 \\
\hline $\mathbf{2 0 1 4}$ & 19.41 & 0.10 & 0.59 & 0.034 & 2.40 & 0.048 & 287.12 & 2.64 \\
\hline $\mathbf{2 0 1 5}$ & 19.83 & 0.13 & 0.44 & 0.023 & 2.50 & 0.051 & 287.31 & 1.65 \\
\hline
\end{tabular}

Wave Height (m) Wave Direction (deg) Upwelling Index Alongshore Ekman

\begin{tabular}{ccccccccc}
\hline Year & Mean & SE & Mean & SE & Mean & SE & Mean & SE \\
\hline $\mathbf{2 0 1 2}$ & 1.043 & 0.0028 & 223.33 & 0.46 & 113.45 & 6.37 & -26.026 & 2.55 \\
\hline $\mathbf{2 0 1 3}$ & - & - & - & - & 118.12 & 5.16 & -19.95 & 1.95 \\
\hline $\mathbf{2 0 1 4}$ & 1.043 & 0.0031 & 222.86 & 0.41 & 93.30 & 4.26 & -16.16 & 1.59 \\
\hline $\mathbf{2 0 1 5}$ & 1.048 & 0.0026 & 222.70 & 0.35 & 96.77 & 4.57 & -20.49 & 1.76 \\
\hline
\end{tabular}


Table 2. Summary table for larval traits. Standard Length $(\mathrm{SL})$ is the length from fish snout to caudal peduncle. Pelagic larval duration (PLD) is the amount of time a larva spends in the water column prior to settlement. 


\begin{tabular}{lcccccccccc}
\hline & $\begin{array}{c}\text { SL at Settlement } \\
(\mathrm{mm})\end{array}$ & \multicolumn{2}{c}{$\begin{array}{c}\text { SL at Collection } \\
(\mathrm{mm})\end{array}$} & \multicolumn{2}{c}{ PLD (days) } & \multicolumn{2}{c}{$\begin{array}{c}\text { Otolith Growth } \\
(\mu \mathrm{m})\end{array}$} & \multicolumn{2}{c}{$\begin{array}{c}\text { Body Condition } \\
\left(\mathrm{mg} \mathrm{mm}^{-3}\right)\end{array}$} \\
\hline Year & Mean & SE & Mean & SE & Mean & SE & Mean & SE & Mean & SE \\
\hline $\mathbf{2 0 1 2}$ & 9.077 & 0.15 & 9.635219 & 0.22 & 25.71 & 0.45 & 51.45 & 0.69 & 0.0043 & 0.00019 \\
\hline $\mathbf{2 0 1 3}$ & 8.77 & 0.19 & 9.440045 & 0.24 & 27.18 & 0.43 & 50.11 & 0.52 & 0.0047 & 0.00044 \\
\hline $\mathbf{2 0 1 4}$ & 9.22 & 0.39 & 10.8685 & 0.48 & 29.56 & 0.89 & 41.32 & 0.87 & 0.0035 & 0.00027 \\
\hline $\mathbf{2 0 1 5}$ & 8.16 & 0.64 & 11.7312 & 0.88 & 28.80 & 1.85 & 101.21 & 12.76 & 0.0032 & 0.00015 \\
\hline
\end{tabular}


Table 3. Summary of all models used to test the relationship between environmental parameters and settlement. Models that carry weight are in bold. K: number of parameters in the model; AICc: Akaike's Information Criterion score adjusted for small sample size; $\triangle \mathrm{AIC}$ : difference in AICc scores between a given model and the most plausible model; AICcWt: weight of a given model; Cum.Wt: cumulative weight of a given model plus the weight of more plausible models; LL: log likelihood; Prop. Dev.: proportion of total deviance explained by the most plausible model. Chl-a: chlorophyll a concentration; SST: sea surface temperature; Avgwind: average wind speed; Maxwind: maximum wind speed; Upwelling: upwelling index; Alongshore: Ekman transport. 


\begin{tabular}{|c|c|c|c|c|c|c|c|}
\hline Model & K & $\mathrm{AICC}$ & $\triangle \mathrm{AICC}$ & AlCcWt & Cum.Wt & LL & $\begin{array}{l}\text { Prop. } \\
\text { Dev. }\end{array}$ \\
\hline $\mathrm{Chl}-\mathrm{a}+\mathrm{Chl}-\mathrm{a}^{2}+\mathrm{SST}+$ Avgwind & 6 & 477.45 & 0 & 0.17 & 0.17 & -232.65 & 0.22 \\
\hline Chl-a + Chl-a + Alongshore & 5 & 477.87 & 0.42 & 0.14 & 0.31 & -233.89 & 0.21 \\
\hline $\mathrm{Chl}-\mathrm{a}+\mathrm{Chl}-\mathrm{a}^{2}$ & 4 & 477.97 & 0.53 & 0.13 & 0.44 & -234.95 & 0.20 \\
\hline Chl-a + Chl-a² + Upwelling + & & & & & & & \\
\hline Avgwind & 6 & 478.16 & 0.72 & 0.12 & 0.56 & -233.01 & 0.22 \\
\hline $\begin{array}{l}\mathrm{Chl}-\mathrm{a}+\mathrm{Chl}-\mathrm{a}^{2}+\mathrm{SST}+\text { Avgwind }+ \\
\text { Maxwind }\end{array}$ & 7 & 478.97 & 1.52 & 0.08 & 0.64 & -232.39 & 0.22 \\
\hline Chl-a + Chl-a ${ }^{2}+\mathrm{SST}+$ Alongshore & 6 & 479.15 & 1.7 & 0.07 & 0.71 & -233.5 & 0.21 \\
\hline Chl-a + Chl-a + SST & 5 & 479.45 & 2 & 0.06 & 0.78 & -234.67 & 0.20 \\
\hline $\begin{array}{l}\text { Chl-a + Chl-a + SST + Avgwind + } \\
\text { Maxwind + Alongshore }\end{array}$ & 8 & 479.45 & 2.01 & 0.06 & 0.84 & -231.61 & 0.23 \\
\hline Chl-a + Chl-a² + Upwelling & 5 & 479.98 & 2.54 & 0.05 & 0.89 & -234.94 & 0.20 \\
\hline $\begin{array}{l}\text { Chl-a + Chl-a }+ \text { SST + Avgwind + } \\
\text { Maxwind + Upwelling + } \\
\text { Alongshore }\end{array}$ & 9 & 480.65 & 3.21 & 0.03 & 0.92 & -231.18 & 0.23 \\
\hline $\begin{array}{l}\text { Chl-a + Chl-a + SST + Avgwind + } \\
\text { Maxwind + Upwelling }\end{array}$ & 8 & 480.67 & 3.23 & 0.03 & 0.96 & -232.22 & 0.22 \\
\hline Chl-a + Chl-a ${ }^{2}+$ SST + Upwelling & 6 & 481.47 & 4.02 & 0.02 & 0.98 & -234.67 & 0.20 \\
\hline $\begin{array}{l}\mathrm{Chl}-\mathrm{a}+\mathrm{Chl}-\mathrm{a}^{2}+\mathrm{SST}+\mathrm{SST}^{2}+ \\
\text { Avgwind + Maxwind + Upwelling } \\
+ \text { Alongshore }\end{array}$ & 10 & 481.71 & 4.26 & 0.02 & 1 & -230.67 & 0.23 \\
\hline $\mathrm{SST}+\mathrm{SST}^{2}$ & 4 & 502.27 & 24.83 & 0 & 1 & -247.1 & 0.10 \\
\hline $\mathrm{SST}+\mathrm{SST}^{2}+\mathrm{Chl}-\mathrm{a}+$ Alongshore & 6 & 503.25 & 25.81 & 0 & 1 & -245.56 & 0.11 \\
\hline $\mathrm{SST}+\mathrm{SST}^{2}+\mathrm{Chl}+$ Avgwind & 6 & 503.49 & 26.04 & 0 & 1 & -245.67 & 0.11 \\
\hline $\mathrm{SST}+\mathrm{SST}^{2}+\mathrm{Chl}$ & 5 & 504.18 & 26.74 & 0 & 1 & -247.04 & 0.10 \\
\hline $\begin{array}{l}\mathrm{SST}+\mathrm{SST}^{2}+\mathrm{Chl}+\text { Avgwind }+ \\
\text { Maxwind + Alongshore }\end{array}$ & 8 & 504.2 & 26.75 & 0 & 1 & -243.98 & 0.13 \\
\hline $\begin{array}{l}\mathrm{SST}+\mathrm{SST}^{2}+\mathrm{Chl}+\text { Avgwind }+ \\
\text { Maxwind }\end{array}$ & 7 & 504.6 & 27.16 & 0 & 1 & -245.21 & 0.12 \\
\hline $\mathrm{SST}+\mathrm{SST}^{2}+\mathrm{Chl}+$ Upwelling & 6 & 505.94 & 28.49 & 0 & 1 & -246.9 & 0.10 \\
\hline $\begin{array}{l}\mathrm{SST}+\mathrm{SST}^{2}+\mathrm{Chl}+\text { Avgwind + } \\
\text { Maxwind + Upwelling }\end{array}$ & 8 & 506.66 & 29.21 & 0 & 1 & -245.21 & 0.12 \\
\hline SST + Alongshore & 4 & 513.72 & 36.28 & 0 & 1 & -252.83 & 0.05 \\
\hline SST & 3 & 514.49 & 37.04 & 0 & 1 & -254.22 & 0.03 \\
\hline SST + Avgwind & 4 & 514.78 & 37.33 & 0 & 1 & -253.36 & 0.04 \\
\hline SST + Avgwind + Maxwind & 5 & 516.39 & 38.95 & 0 & 1 & -253.15 & 0.04 \\
\hline SST + Upwelling & 4 & 516.4 & 38.95 & 0 & 1 & -254.17 & 0.03 \\
\hline $\mathrm{Chl}+\mathrm{SST}$ & 4 & 516.48 & 39.03 & 0 & 1 & -254.2 & 0.03 \\
\hline
\end{tabular}


Table 3. Summary of all models used to test the relationship between environmental parameters and settlement. Continued from the previous page. $\mathrm{K}$ : number of parameters in the model; AICc: Akaike's Information Criterion score adjusted for small sample size; $\triangle \mathrm{AICc}$ : difference in AICc scores between a given model and the most plausible model; AICcWt: weight of a given model; Cum.Wt: cumulative weight of a given model plus the weight of more plausible models; LL: log likelihood; Prop. Dev.: proportion of total deviance explained by the most plausible model. Chl-a: chlorophyll a concentration; SST: sea surface temperature; Avgwind: average wind speed; Maxwind: maximum wind speed; Upwelling: upwelling index; Alongshore: Ekman transport. 


\begin{tabular}{lccccccc}
\hline & & & & & & & Prop. \\
Model & $\mathrm{K}$ & AICc & $\Delta$ AICc & AlCcWt & Cum.Wt & LL & Dev. \\
\hline SST + Maxwind & 4 & 516.51 & 39.07 & 0 & 1 & -254.22 & 0.03 \\
\hline Chl + Avgwind + Alongshore & 5 & 516.54 & 39.09 & 0 & 1 & -253.22 & 0.04 \\
\hline Chl + SST + Avgwind & 5 & 516.62 & 39.17 & 0 & 1 & -253.26 & 0.04 \\
\hline Chl + Avgwind & 4 & 517.14 & 39.69 & 0 & 1 & -254.54 & 0.03 \\
\hline Chl & 3 & 517.26 & 39.82 & 0 & 1 & -255.61 & 0.02 \\
\hline Alongshore & 3 & 517.76 & 40.32 & 0 & 1 & -255.86 & 0.02 \\
\hline Chl + Maxwind + Alongshore & 5 & 518.11 & 40.67 & 0 & 1 & -254.01 & 0.03 \\
\hline Chl + SST + Avgwind + Maxwind & 6 & 518.23 & 40.78 & 0 & 1 & -253.04 & 0.03 \\
\hline Upwelling + Alongshore & 4 & 518.44 & 41 & 0 & 1 & -255.19 & 0.02 \\
\hline Chl + Avgwind + Maxwind & 5 & 519 & 41.56 & 0 & 1 & -254.45 & 0.03 \\
\hline Chl + Avgwind + Upwelling & 5 & 519.16 & 41.71 & 0 & 1 & -254.53 & 0.03 \\
\hline Chl + Maxwind & 4 & 519.22 & 41.77 & 0 & 1 & -255.58 & 0.02 \\
\hline Chl + SST + Avgwind + Maxwind + & & & & & & & \\
Upwelling + Alongshore & 8 & 519.72 & 42.27 & 0 & 1 & -251.74 & 0.06 \\
\hline Avgwind & 3 & 519.75 & 42.31 & 0 & 1 & -256.86 & 0.01 \\
\hline Chl + SST + Avgwind + Maxwind + & & & & & & & \\
Upwelling & 7 & 520.27 & 42.83 & 0 & 1 & -253.04 & 0.04 \\
\hline Upwelling & 3 & 520.51 & 43.06 & 0 & 1 & -257.23 & 0.00 \\
\hline Maxwind & 3 & 520.66 & 43.21 & 0 & 1 & -257.31 & 0.00 \\
\hline Chl + Maxwind + Upwelling & 5 & 521.18 & 43.73 & 0 & 1 & -255.54 & 0.02 \\
\hline & & & & & & & \\
\hline & & & 0 & & & & \\
\hline
\end{tabular}


Table 4. Summary of slopes with $95 \%$ confidence intervals for the models that carry weight. Slopes with confidence intervals that do not overlap 0 have a significant effect on settlement and are in bold. 


\begin{tabular}{lc}
\hline & Slope \\
\hline SST & $0.19(-0.77$ to 1.14$)$ \\
\hline Chl-a & $\mathbf{8 . 4 7 ( 5 . 3 4 5}$ to $\mathbf{1 1 . 6 1 )}$ \\
\hline Chl-a & $\mathbf{- 3 . 8 5 ( - 5 . 4 2}$ to $-\mathbf{2 . 2 9})$ \\
\hline Avg Wind & $\mathbf{- 0 . 2 3 ( - 0 . 4 4 \text { to } - \mathbf { 0 . 0 1 1 } )}$ \\
\hline Max Wind & $0.052(-0.072$ to 0.18$)$ \\
\hline Upwelling & $0.0012(-0.0044$ to 0.0068$)$ \\
\hline Alongshore & $0.011(-0.0029$ to 0.024$)$ \\
\hline
\end{tabular}


Table 5. Output of repeated measures multivariate analysis of variance (MANOVA), comparing daily otolith growth of all fish among years. For all test methods, otolith growth was found significantly different among years $(p<0.05)$. 


\begin{tabular}{lccccc}
\hline Test & Value & $\mathrm{F}$ & Hypothesis df & Error df & Sig. \\
\hline Pillai's Trace & 0.855 & 52.960 & 3.000 & 27.000 & 0.000 \\
\hline Wilks' Lambda & 0.145 & 52.960 & 3.000 & 27.000 & 0.000 \\
\hline Hotelling's Trace & 5.884 & 52.960 & 3.000 & 27.000 & 0.000 \\
\hline Roy's Largest Root & 5.783 & 52.960 & 3.000 & 27.000 & 0.000 \\
\hline
\end{tabular}


Table 6. Data for average proportional settlement relative to lunar day for each year.

Lunar day 1 marks a full moon. 


\begin{tabular}{|c|c|c|c|c|}
\hline \multirow[b]{2}{*}{ Lunar Day } & \multicolumn{4}{|c|}{ Proportion of Settlement } \\
\hline & 2012 & 2013 & 2014 & 2015 \\
\hline 1 & 1.14 & 0.00 & 0.00 & 0.00 \\
\hline 2 & 1.14 & 1.82 & 0.00 & 0.00 \\
\hline 3 & 7.58 & 0.00 & 0.00 & 0.00 \\
\hline 4 & 9.47 & 0.00 & 12.50 & 10.00 \\
\hline 5 & 0.00 & 4.00 & 3.57 & 0.00 \\
\hline 6 & 6.82 & 0.00 & 0.00 & 0.00 \\
\hline 7 & 0.00 & 4.00 & 28.57 & 0.00 \\
\hline 8 & 0.00 & 0.00 & 0.00 & 20.00 \\
\hline 9 & 0.00 & 0.00 & 0.00 & 0.00 \\
\hline 10 & 5.30 & 3.08 & 19.64 & 0.00 \\
\hline 11 & 4.17 & 6.15 & 3.57 & 0.00 \\
\hline 12 & 0.00 & 10.15 & 0.00 & 0.00 \\
\hline 13 & 2.27 & 3.08 & 0.00 & 0.00 \\
\hline 14 & 0.00 & 29.23 & 0.00 & 10.00 \\
\hline 15 & 0.00 & 3.08 & 12.50 & 0.00 \\
\hline 16 & 6.44 & 0.00 & 0.00 & 0.00 \\
\hline 17 & 0.00 & 2.73 & 0.00 & 20.00 \\
\hline 18 & 0.00 & 4.00 & 0.00 & 0.00 \\
\hline 19 & 0.00 & 3.08 & 0.00 & 0.00 \\
\hline 20 & 0.00 & 0.00 & 0.00 & 0.00 \\
\hline 21 & 0.00 & 0.91 & 16.07 & 0.00 \\
\hline 22 & 0.00 & 0.00 & 0.00 & 0.00 \\
\hline 23 & 0.00 & 0.91 & 0.00 & 0.00 \\
\hline 24 & 1.14 & 0.91 & 0.00 & 0.00 \\
\hline 25 & 0.00 & 8.18 & 0.00 & 0.00 \\
\hline 26 & 25.00 & 0.91 & 3.57 & 0.00 \\
\hline 27 & 17.05 & 0.00 & 0.00 & 0.00 \\
\hline 28 & 0.00 & 11.06 & 0.00 & 0.00 \\
\hline 29 & 0.00 & 1.82 & 0.00 & 0.00 \\
\hline 30 & 0.00 & 0.91 & 0.00 & 0.00 \\
\hline 31 & 12.50 & 0.00 & 0.00 & 20.00 \\
\hline
\end{tabular}


Table 7. Summary of p-values of multiple regressions run for combination of listed factors and settlement of spotted sand bass. Each form of Chl-a (daily, 1 wk lag, 2 wk lag, 3 wk lag) was used in its own regression. Significant factors are in bold. 


\begin{tabular}{cccccc}
\hline Factor & 2012 & 2013 & 2014 & 2015 & All Years \\
\hline SST & 0.931 & 0.515 & 0.683 & 0.987 & $\mathbf{0 . 0 2 7}$ \\
\hline Chl-a & 0.522 & 0.297 & 0.736 & 0.564 & $\mathbf{0 . 0 1 3}$ \\
\hline 1 wk Chl-a & 0.288 & 0.183 & 0.272 & 0.880 & 0.508 \\
\hline 2 wk Chl-a & 0.198 & $\mathbf{0 . 0 2 8}$ & 0.909 & 0.749 & 0.805 \\
\hline 3 wk Chl-a & 0.845 & 0.956 & 0.976 & 0.470 & 0.257 \\
\hline Avg Wind Speed & 0.616 & 0.422 & $\mathbf{0 . 0 1 8}$ & $\mathbf{0 . 0 2 8}$ & 0.320 \\
\hline Max Wind Speed & 0.661 & 0.538 & 0.346 & 0.216 & 0.986 \\
\hline
\end{tabular}

